\title{
Room-Temperature Phosphorescence and Efficient Singlet Oxygen Production by Cyclometalated Pt(II) Complexes with Aromatic Alkynyl Ligands
}

\author{
Ariadna Lázaro, Carla Cunha, Ramon Bosque, João Pina, Jas S. Ward, Khai-Nghi Truong, Kari Rissanen, \\ João Carlos Lima, Margarita Crespo, J. Sérgio Seixas de Melo,* and Laura Rodríguez*
}

Cite This: Inorg. Chem. 2020, 59, 8220-8230

Read Online

ABSTRACT: The synthesis of five novel cyclometalated platinum(II) compounds containing five different alkynyl-chromophores was achieved by the reaction of the previously synthesized $\mathrm{Pt}-\mathrm{Cl}$ cyclometalated compound (1) with the corresponding $\mathrm{RC} \equiv \mathrm{CH}$ by a Sonogashira reaction. It was observed that the spectral and photophysical characteristics of the cyclometalated platinum(II) complexes (Pt-Ar) are essentially associated with the platinum-cyclometalated unit. Room-temperature emission of the $\mathrm{Pt}-\mathrm{Ar}$ complexes was attributed to phosphorescence in agreement with DFT calculations. Broad nanosecond (ns)-transient absorption spectra were observed with decays approximately identical to

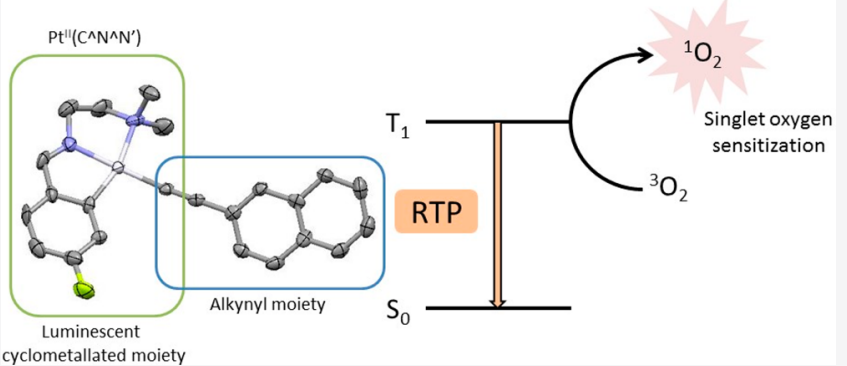
those obtained from the emission of the triplet state. From the femtosecond-transient absorption (fs-TA) data, two main excitedstate decay components were identified: one in the order of a few picoseconds was assigned to fast intersystem crossing to populate the triplet excited-state and the second (hundreds of ns) was associated with the decay of the transient triplet state. In general, efficient singlet oxygen photosensitization quantum yields were observed from the triplet state of these complexes.

\section{INTRODUCTION}

Organometallic materials containing $\pi$-conjugated entities have emerged as a frontier research field in the past few decades, owing to their application in different fields such as organic light-emitting diodes (OLEDs), organic photovoltaic devices, and materials for nonlinear absorption. ${ }^{1}$ Cyclometalated complexes of late transition metals are particularly interesting in this field, mainly for their outstanding luminescent properties. Such complexes typically feature pronounced ligand-involved components (e.g., MLCT or ILCT) in their lowest triplet excited state, which facilitate radiative decays, turning emission into a competitive pathway in relation to the nonradiative relaxation processes. The photophysical properties of the cyclometalated complexes are consequently sensitively influenced by both the cyclometalated and ancillary ligands. This makes possible the convenient tailoring of the photophysical properties by modifying the ligand structures. ${ }^{2}$ However, heavy atom complexes that contain $\pi$-conjugated units are particularly relevant in achieving efficient nonlinear absorption by a "dual mode" pathway. This is due to the facility of harvesting triplet excited states through the spinorbit coupling effect. ${ }^{3,4}$ In particular, it is well-known that the presence of a heavy metal ion enhances the intersystem crossing (ISC) process which is usually competitive with fluorescence. Thus, many of these types of complexes display dual fluorescence and phosphorescence.
In general, the photoexcitation of cyclometalated complexes populates initially singlet excited states $\left({ }^{1} \mathrm{MLCT}\right.$ and $\left.{ }^{1} \mathrm{LC}\right)$ and then quickly undergoes ISC to the triplet excited states with high efficiency. The lowest triplet excited state is typically described as a mixed ${ }^{3} \mathrm{MLCT} /{ }^{3} \mathrm{LC}$ state, ${ }^{2}$ but it can also include other states such as ${ }^{3} \mathrm{ILCT},{ }^{3} \mathrm{LLCT},{ }^{3} \mathrm{LMMCT}$, ${ }^{3} \mathrm{MMLCT}$, or ${ }^{3} \mathrm{MLLCT} .{ }^{1}$ As a result, cyclometalated complexes have gained great interest in applications in different fields such as dopants in OLEDs, photocatalysts, biological signaling compounds, optical sensors, nonlinear optical materials, solid-state light-emitting electrochemical cells, or photodynamic therapy (PDT) photosensitizers. ${ }^{5-12}$ Cyclic tetrapyrrolic structures, such as porphyrins and phthalocyanines, are one of the most intensively investigated classes of PDT photosensitizers. Nevertheless, important drawbacks have been observed in these systems, such as the long synthetic steps with low yields and the difficulty for modulating their photophysical and biological properties. ${ }^{13}$ These drawbacks

Received: February 22, 2020

Published: May 29, 2020 
Scheme 1. Synthesis, Structures and Acronyms of the Cyclometalated Platinum(II) Complexes and the Uncoordinated Ligands ${ }^{a}$

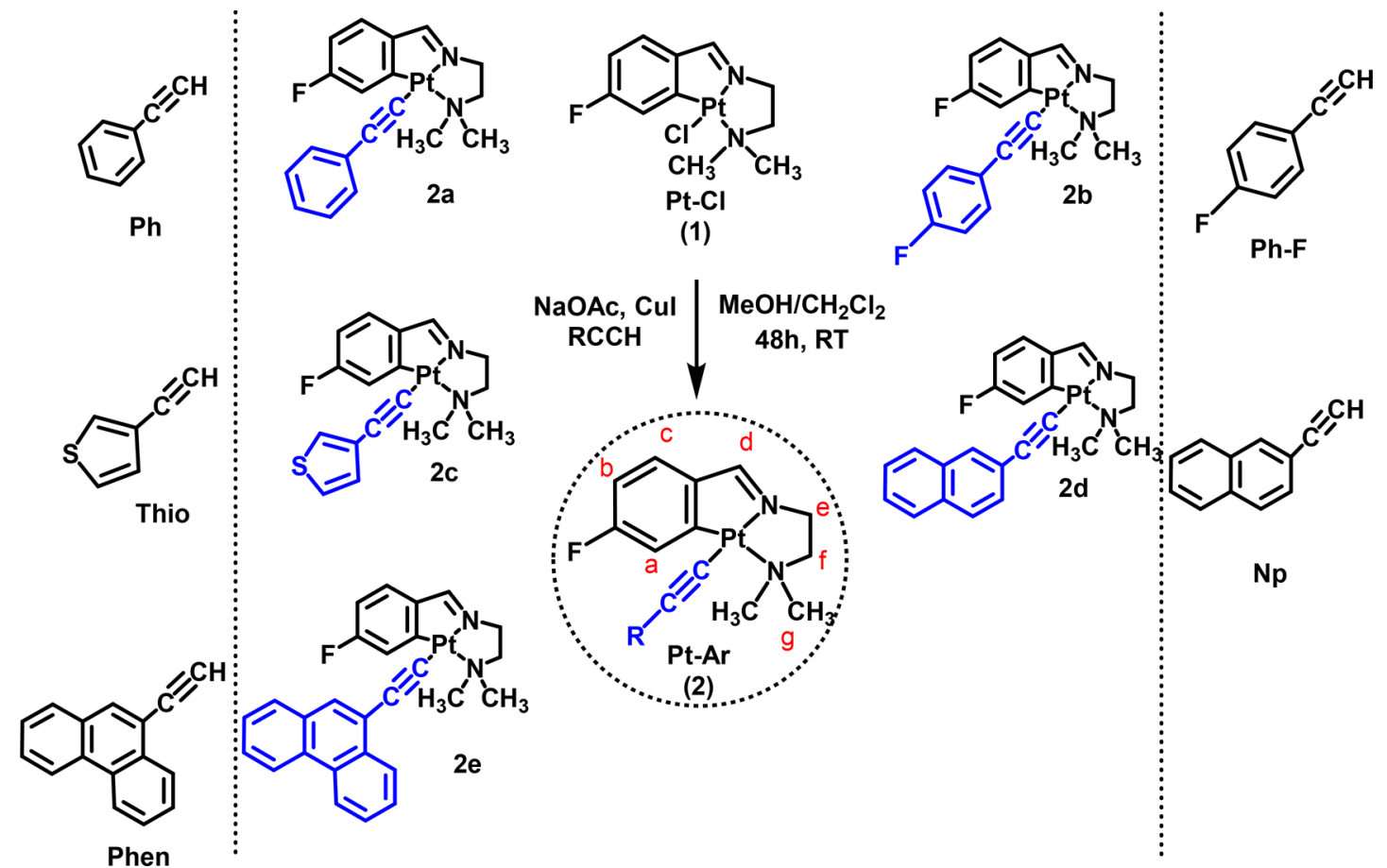

${ }^{a}$ Uncoordinated ligands are on the left and right hands of the picture. The letters in $\mathrm{Pt}-\mathrm{Ar}$ (2) are used for NMR assignment

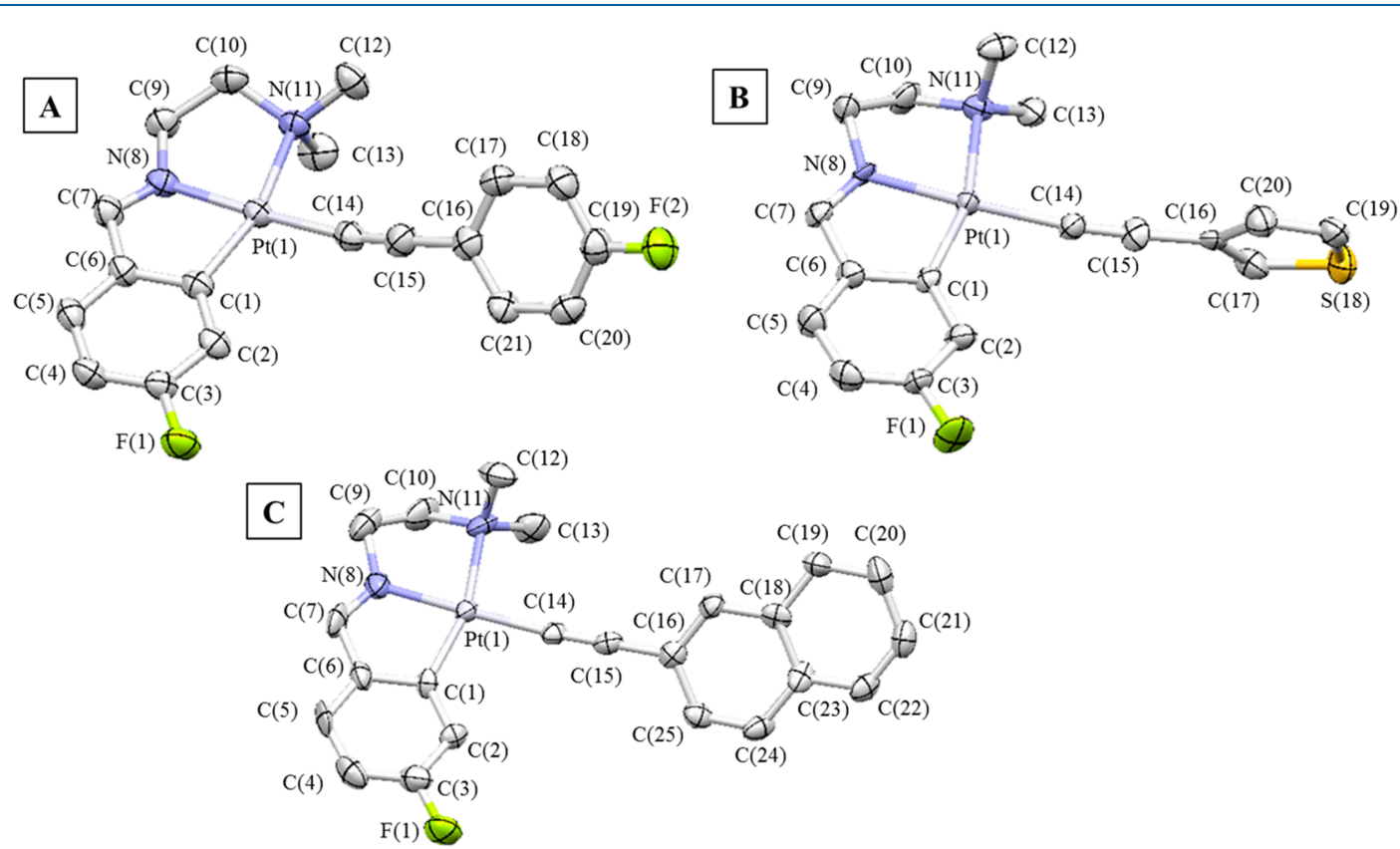

Figure 1. Molecular structures of compounds $2 \mathbf{b}(\mathrm{A}), \mathbf{2 c}(\mathrm{B})$, and $\mathbf{2 d}(\mathrm{C})$. Selected bond lengths $(\AA)$ and angles (deg) with estimated standard deviations. For 2b: $\mathrm{Pt}(1)-\mathrm{N}(8): 2.010(6) ; \mathrm{Pt}(1)-\mathrm{N}(11): 2.176(5) ; \mathrm{Pt}(1)-\mathrm{C}(14): 2.002(7) ; \mathrm{Pt}(1)-\mathrm{C}(1): 1.999(6) ; \mathrm{C}(14)-\mathrm{C}(15): 1.161(9)$; $\mathrm{N}(8)-\mathrm{Pt}(1)-\mathrm{N}(11): 81.9(2) ; \mathrm{C}(1)-\mathrm{Pt}(1)-\mathrm{N}(8): 81.5(2) ; \mathrm{C}(1)-\mathrm{Pt}(1)-\mathrm{C}(14)$ : 97.2(3); C(14)-Pt(1)-N(11): 99.1(2); $\mathrm{Pt}(1)-\mathrm{C}(14)-$ $\mathrm{C}(15):$ 170.05. For 2c: $\operatorname{Pt}(1)-\mathrm{N}(8): 2.001(11) ; \mathrm{Pt}(1)-\mathrm{N}(11): 2.157(12) ; \mathrm{Pt}(1)-\mathrm{C}(14): 1.992(15) ; \operatorname{Pt}(1)-\mathrm{C}(1): 1.984(14) ; \mathrm{C}(14)-\mathrm{C}(15)$ : $1.180(2) ; \mathrm{N}(8)-\mathrm{Pt}(1)-\mathrm{N}(11): 81.6(5) ; \mathrm{C}(1)-\mathrm{Pt}(1)-\mathrm{N}(8): 81.6(5) ; \mathrm{C}(1)-\mathrm{Pt}(1)-\mathrm{C}(14): 100.0(6) ; \mathrm{C}(14)-\mathrm{Pt}(1)-\mathrm{N}(11): 96.7(5) ; \mathrm{Pt}(1)-$ $\mathrm{C}(14)-\mathrm{C}(15): 174.03$. For 2d: $\mathrm{Pt}(1)-\mathrm{N}(8): 1.990(11) ; \mathrm{Pt}(1)-\mathrm{N}(11): 2.161(11) ; \mathrm{Pt}(1)-\mathrm{C}(14): 1.963(13) ; \mathrm{Pt}(1)-\mathrm{C}(1): 2.005(14) ; \mathrm{C}(14)-$ $\mathrm{C}(15): 1.199(18) ; \mathrm{N}(8)-\mathrm{Pt}(1)-\mathrm{N}(11): 82.4(5) ; \mathrm{C}(1)-\mathrm{Pt}(1)-\mathrm{N}(8)$ : 81.5(5); C(1)-Pt(1)-C(14): 98.1(5); C(14)-Pt(1)-N(11): 98.1(5); $\mathrm{Pt}(1)-\mathrm{C}(14)-\mathrm{C}(15): 174.72$. The thermal ellipsoids are drawn at the $50 \%$ probability level.

can be easily overcome in other complexes such as cyclometalated derivatives, where the photophysical parameters can be systematically tuned by changes of the electronic character- istics of the complex as for porphyrins and phthalocyanines. ${ }^{13}$ One of the first reports on cyclometalated $\mathrm{Pt}(\mathrm{II})$ complexes used for singlet oxygen sensitization was contributed by 
Weinstein and co-workers in $2006^{14}$ and some other $\mathrm{Pt}(\mathrm{II})$ cyclometalated complexes with more or less efficiency have been published to date. ${ }^{2}$ The higher efficiency of $\mathrm{Pt}(\mathrm{II})$ over other heavy atoms such as $\operatorname{Ir}(\mathrm{III})$ is attributed to its squareplanar geometry that avoids steric hindrances and eases the interaction with dioxygen molecule.

Taking all of this into consideration, in this work, we have designed and synthesized a series of five new $\mathrm{Pt}(\mathrm{II})$ cyclometalated compounds that differ on the ancillary ligand which is an alkynyl-chromophore. Some examples of luminescent $\mathrm{Pt}\left[\mathrm{C}^{\wedge} \mathrm{N}^{\wedge} \mathrm{N}\right]$ cyclometalated complexes have already been reported in the literature, and to the best of our knowledge, in all of them the three $\left[\mathrm{C}^{\wedge} \mathrm{N}^{\wedge} \mathrm{N}\right]$ coordination positions belong to an aromatic cycle. ${ }^{15-19}$ The photophysical characterization of $\mathrm{Pt}\left[\mathrm{C}^{\wedge} \mathrm{N}^{\wedge} \mathrm{N}\right]$ cyclometalated compounds containing a tridentate $\left[\mathrm{C}^{\wedge} \mathrm{N}^{\wedge} \mathrm{N}^{\prime}\right]$ imine ligand and alkynylchromophoric units occupying the fourth coordination position of the metal sphere is herein reported for the first time. Their potential as photosensitizers for singlet oxygen production was also evaluated.

\section{RESULTS AND DISCUSSION}

Synthesis and Characterization. The syntheses of the compounds were carried out following the strategy summarized in Scheme 1 by slight modifications of the previously reported Sonogashira method. ${ }^{20}$ Parent cyclometalated compound 1 reacted with the alkynyl aromatic chromophore $\mathrm{RC} \equiv \mathrm{CH}$ in the presence of sodium acetate as a base and $\mathrm{CuI}$ as a catalyst.

The compounds were obtained as orange solids after precipitation and washing with hexane in moderate to high yields $(55-85 \%)$. All compounds were characterized by mass spectra and ${ }^{1} \mathrm{H}$ and ${ }^{19} \mathrm{~F}$ NMR spectra. ${ }^{1} \mathrm{H}$ NMR of all compounds display the disappearance of the terminal alkynyl proton as a direct indication of coordination together with the corresponding protons of this new ancillary ligand. As previously observed, the dimethylamino protons $\mathrm{H}^{\mathrm{g}}$ appear as a singlet around $3 \mathrm{ppm}$ integrating for $6 \mathrm{H}$ and coupled to platinum and the imine proton is also coupled to platinum. Additionally, $\mathrm{H}^{\mathrm{a}}$ aromatic proton is also observed to couple to platinum with a ${ }^{3} J(\mathrm{Pt}-\mathrm{H})$ of ca. $70.2 \mathrm{~Hz}$. The ${ }^{19} \mathrm{~F}$ NMR spectra show only one signal, as a broad singlet, which is not significantly affected by the exchange of chloride to alkynylaromatic group. A second signal is present in the NMR of compound $\mathbf{2 b}$ due to the aromatic $p$-fluorobenzene moiety (Figures S1-S10).

Further confirmation of the successful formation of the product was gained from the $\mathrm{C} \equiv \mathrm{C}$ vibration determined by IR spectroscopy and by the determination of the protonated molecular peak in all cases recorded by $\operatorname{ESI}(+)$ spectrometry (Figures S11-S15).

Single crystals suitable for X-ray diffraction analysis were grown for $\mathbf{2 b}, \mathbf{2 c}$, and $\mathbf{2 d}$ (Figure 1 and Table S1). One single molecule is present in the asymmetric units of $\mathbf{2 b}$ and $\mathbf{2 d}$, while three independent molecules are observed in the asymmetric unit of 2c (Figure S16). Pt...Pt distances are ca. 3.9 and $4.4 \AA$ and thus, metallophilic interactions are excluded in this asymmetric unit. The unit cells, shown in Figures S17S19A, contain 4 (2b and 2 d) or 12 molecules (2c). As expected, in all cases the platinum adopts a square-planar coordination completed with the tridentate $\left[\mathrm{C}^{\wedge} \mathrm{N}^{\wedge} \mathrm{N}^{\prime}\right]$ ligand and an alkynyl-chromophore ligand trans to the imine. Bond lengths and angles are in the same range as those previously reported in the literature for $\mathrm{Pt}(\mathrm{II})$ cyclometalated complexes. ${ }^{11,12}$ The alkynyl chromophore is at a near-linear conformation with the $\mathrm{Pt}$ metal atom, with angles around $170-175^{\circ}$ and its aromatic ring is almost perpendicular to the square-planar $\left[\mathrm{C}^{\wedge} \mathrm{N}^{\wedge} \mathrm{N}^{\prime}\right]-\mathrm{Pt}$ plane. The $3 \mathrm{D}$ packing of $2 \mathrm{c}$ and 2d shows intermolecular short contacts involving the fluorine atom $(\mathrm{F}(1) \cdots \mathrm{H}(9 \mathrm{~b})=2.551 \AA$ for $2 \mathrm{c}$ and $\mathrm{F}(1) \cdots \mathrm{H}(17)=$ $2.552 \AA$ for $2 \mathrm{~d}$ ), while for $\mathbf{2 b}$ the most relevant intermolecular short contacts involve the platinum atom or the alkynyl moiety $(\mathrm{Pt}(1) \cdots \mathrm{H}(21)=2.782 \AA$ and $\mathrm{C}(15) \cdots \mathrm{H}(9 \mathrm{~B})=2.689 \AA)$, as depicted in Figures S17-S19B.

Electronic Spectral and Photophysical Characterization. The absorption spectra of the platinum(II) compounds $1(\mathrm{Pt}-\mathrm{Cl})$ and $\mathbf{2 a}-\mathbf{e}(\mathrm{Pt}-\mathrm{Ar})$ show several bands in the UV-visible range with moderate molar extinction coefficient, $\varepsilon$, values (Figure 2 and Table 1 ). The lowest energy

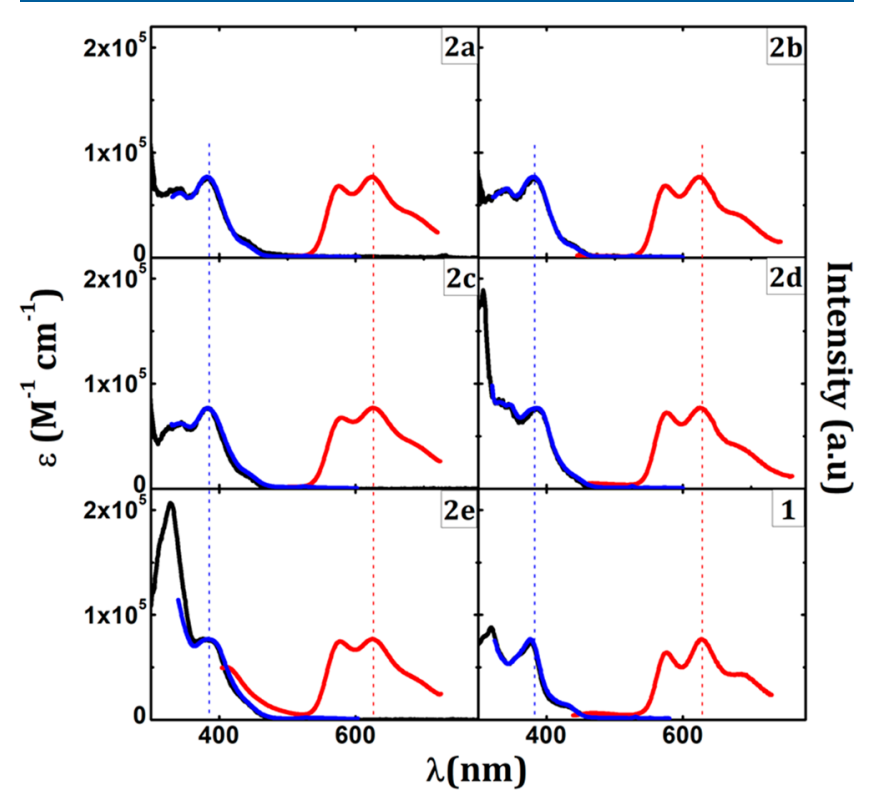

Figure 2. Normalized absorption (black line) together with the phosphorescence excitation (blue line) and emission (red line) spectra for $1.3 \times 10^{-5} \mathrm{M}$ acetonitrile solutions of the $\mathrm{Pt}-\mathrm{Ar}$ complexes $(\mathbf{2 a}-\mathbf{e})$ and $\mathrm{Pt}-\mathrm{Cl}(\mathbf{1})$ at $293 \mathrm{~K}$.

band with maxima at around $380 \mathrm{~nm}$ can be attributed, in agreement with previous data, to $\operatorname{Pt}(5 \mathrm{~d})-\pi^{*}(\mathrm{~L})$ MLCT mixed

Table 1. Spectral Data for the Pt-Ar Complexes in Acetonitrile $(\mathrm{MeCN})$ at Room Temperature $(293 \mathrm{~K})$

\begin{tabular}{|c|c|c|c|c|}
\hline compound & $\left(\varepsilon \times 10^{-3}, \mathrm{M}^{-1} \mathrm{~cm}^{-1}\right)^{a}$ & $\begin{array}{c}\lambda_{\mathrm{em}}^{\max } \\
(\mathrm{nm})^{b}\end{array}$ & $\begin{array}{l}\lambda_{\max }^{T_{1} \rightarrow T_{\mathrm{n}}} \\
(\mathrm{nm})^{c}\end{array}$ & $\underset{\left(\mathrm{cm}^{-1}\right)^{d}}{\Delta_{\mathrm{ss}}}$ \\
\hline 1 & $378(7.7)$ & 629 & 460 & 10557 \\
\hline $2 a$ & $\begin{array}{l}282(21.6), 342(6.6), 382 \\
\quad(7.6)\end{array}$ & 624 & 540 & 10152 \\
\hline $2 b$ & $\begin{array}{l}278(21.2), 342(6.9), 382 \\
\quad(7.7)\end{array}$ & 625 & 540 & 10178 \\
\hline $2 c$ & $\begin{array}{l}280(14.7), 342(5.6), 382 \\
(6.2)\end{array}$ & 626 & 540 & 10204 \\
\hline $2 d$ & $\begin{array}{l}297(8.0), 309(8.2), 386 \\
\quad(7.1)\end{array}$ & 626 & 490 & 9932 \\
\hline $2 \mathrm{e}$ & $333(10.1), 380(7.5)$ & 624 & 540 & 10290 \\
\hline
\end{tabular}

${ }^{a}$ Wavelength absorption; molar extinction coefficients in parentheses. ${ }^{b}$ Phosphorescence maxima. ${ }^{c}$ Transient $\mathrm{T}_{1} \rightarrow \mathrm{T}_{n}$ maxima. ${ }^{d}$ Stokes shift, $\Delta_{\mathrm{SS}}\left(\mathrm{cm}^{-1}\right)$. 
Table 2. Room-Temperature Photophysical Parameters for Pt-Ar and Parent Compound 1

$\begin{array}{cccccccccc}\text { compound } & \begin{array}{c}\phi_{\mathrm{Ph}} \\ \left(\text { with } \mathrm{O}_{2}\right)^{a}\end{array} & \begin{array}{c}\phi_{\mathrm{Ph}}^{0} \\ \left(\mathrm{~N}_{2} \text { sat. }\right)^{a}\end{array} & \begin{array}{c}\tau_{\mathrm{Ph}}^{0}(\mathrm{~ns}) \\ \left(\mathrm{N}_{2} \text { sat. }\right)^{a}\end{array} & \begin{array}{c}\tau_{\mathrm{T}}(\mathrm{ns}) \\ \left(\mathrm{N}_{2} \text { sat. }\right)^{a}\end{array} & \begin{array}{c}\phi_{\Delta} \\ \left(\text { with } \mathrm{O}_{2}\right)^{b}\end{array} & \phi_{\mathrm{IC}}^{S_{1} \rightarrow \mathrm{S}_{0} c} & k_{\mathrm{ET}} \times 10^{6}(\mathrm{~s})^{c} & k_{\mathrm{Ph}} \times 10^{6}(\mathrm{~s})^{c} & k_{\mathrm{ISC}}^{\mathrm{T}_{1} \sim \mathrm{S}_{0}} \times 10^{6}(\mathrm{~s})^{c} \\ \mathbf{1} & 0.005 & 0.016 & 353 & 423 & 0.47 & 0.53 & 6.23 & 0.07 & 2.76 \\ \mathbf{2 a} & 0.005 & 0.023 & 438 & 630 & 0.21 & 0.79 & 8.21 & 0.20 & 2.09 \\ \mathbf{2 b} & 0.007 & 0.023 & 491 & 700 & 0.11 & 0.89 & 4.66 & 0.30 & 1.74 \\ \mathbf{2 c} & 0.009 & 0.018 & 557 & 650 & 0.29 & 0.71 & 1.80 & 0.06 & 1.74 \\ \mathbf{2 d} & 0.008 & 0.025 & 464 & 700 & 0.12 & 0.88 & 4.58 & 0.31 & 1.85 \\ \mathbf{2 e} & 0.008 & 0.028 & 579 & 1200 & 0.16 & 0.84 & 4.32 & 0.22 & 1.51\end{array}$

${ }^{a}$ Phosphorescence quantum yields, $\phi_{\mathrm{Ph}}$, and lifetimes, $\tau_{\mathrm{Ph}}^{\mathrm{o}}$ (obtained using the time-correlated single-photon counting technique), together with triplet-state lifetimes (from ns-ms laser flash photolysis) obtained in aerated (with $\left.\mathrm{O}_{2}\right)$ or degassed $\left(\mathrm{N}_{2}\right.$ saturated, $\mathrm{N}_{2}$ sat.) acetonitrile solutions. ${ }^{b}$ Singlet oxygen sensitization quantum yields $\left(\phi_{\Delta}\right)$. ${ }^{c}$ Internal conversion quantum yields $\left(\phi_{\mathrm{IC}}\right)$ and associated rate constants, $k_{\mathrm{ETT}}$, radiative phosphorescence decay, $k_{\mathrm{Ph}}$, and intersystem crossing, $k_{\mathrm{ISC}}^{\mathrm{T}_{1} \sim \rightarrow \mathrm{S}_{0}} \cdot \phi_{\mathrm{IC}}^{\mathrm{S}_{1} \rightarrow \mathrm{S}_{0}}=1-\phi_{\mathrm{F}}-\phi_{\mathrm{T}}$, assuming $\phi_{\mathrm{F}} \rightarrow 0$ and unitary singlet oxygen sensitization efficiency $S_{\Delta}=\frac{\phi_{T}}{\phi_{\Delta}}=1$ and therefore $\phi_{\mathrm{T}} \cong \phi_{\Delta}$.
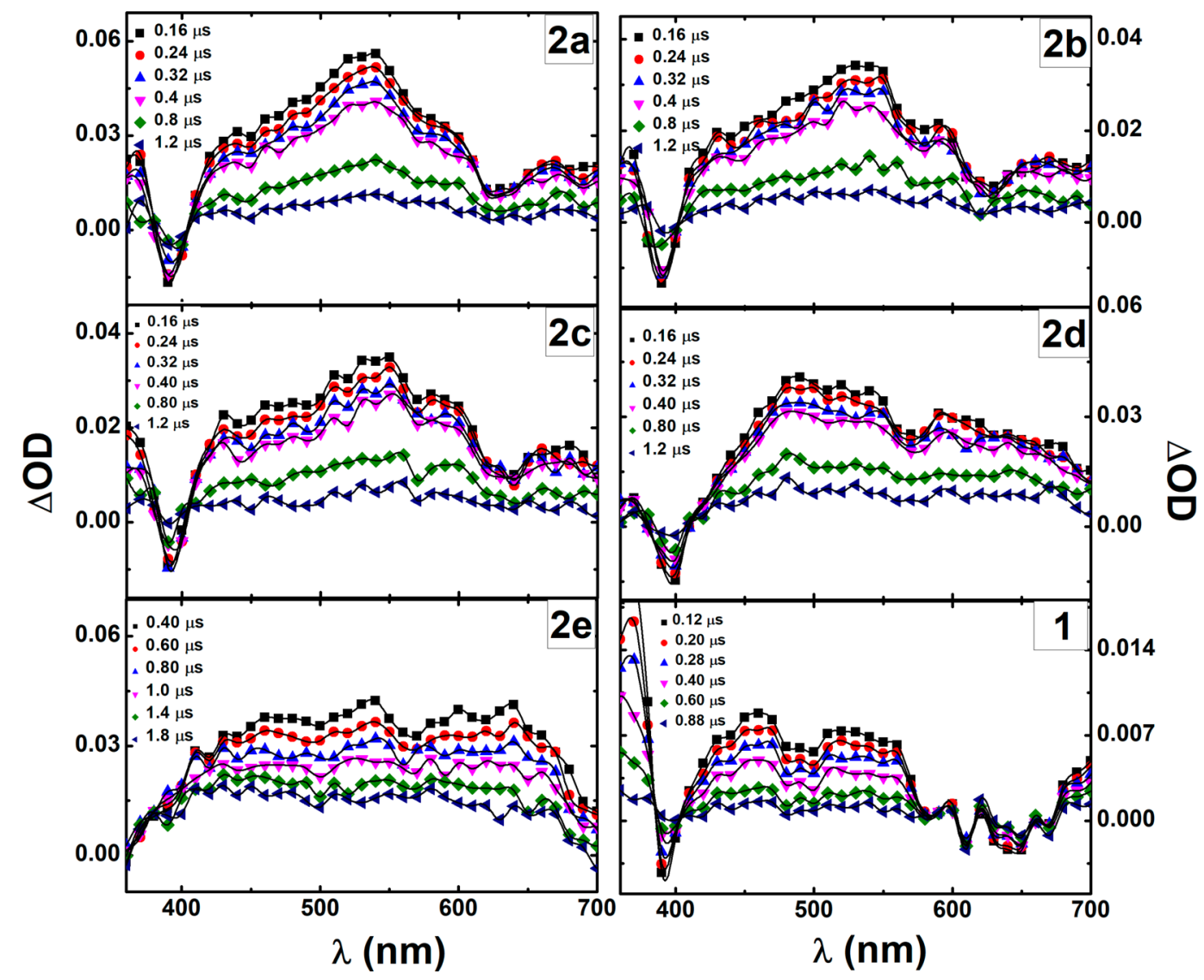

Figure 3. Room-temperature time-resolved transient triplet-triplet absorption spectra for the $\mathrm{Pt}-\mathrm{Ar}$ derivatives $(\mathbf{2 a}-\mathbf{e})$ and $\mathrm{Pt}-\mathrm{Cl}(\mathbf{1})$ collected by laser flash photolysis at $355 \mathrm{~nm}$ (ns-TA) in degassed acetonitrile solutions.

with intraligand transitions. ${ }^{6,12,21-23}$ A higher energy absorption band can be also observed in the $280-300 \mathrm{~nm}$ range with higher $\varepsilon$ values. This band is also recorded for the uncoordinated alkynyl ligands, and for this reason, it can be assigned to $\pi-\pi^{*}$ intraligand transitions. ${ }^{11}$ Additional intraligand transitions typical for phenanthryl or naphthyl chromophores are buried under the absorption of the complexes. DFT theoretical calculations support these assignments (see below).

It is thus clear from the absorption spectra that the cyclometalated unit dominates the spectral features of these compounds (similar profiles were observed for $\mathbf{1}$ and $\mathbf{2 a - e}$, see Figure 2), which is in agreement with the fact that (via visual observation) the new alkynyl aromatic ligands do not affect the resulting color of the powders. Moreover, the absorption spectra of the Pt-Ar complexes (Figures 2 and S20) match the excitation (Figure S21) spectra, which is a strong clue of the purity of the complexes (together with the characterization data) thus showing that the emission is due to both the Ptcyclometalated and alkynyl-chromophoric moieties.

The luminescence spectra of the $\mathrm{Pt}-\mathrm{Ar}$ compounds show a vibronically structured band centered at ca. $625 \mathrm{~nm}$, found independent of the excitation wavelength (Figure 2). The recorded band presents a vibronic structure with progressional spacing of $1200 \mathrm{~cm}^{-1}$, typical of $v(\mathrm{C}=\mathrm{C})$ and $v(\mathrm{C}=\mathrm{N})$ stretching frequencies, that demonstrates the involvement of the ligand character in their emission origin. The large Stokes' shift and the quenching of the band intensity in the presence of 
oxygen (Table 1 and Figure S22) strongly indicate the origin of this luminescence to be the emission from the triplet state, i.e., phosphorescence. This is further confirmed from ns- and fs-TA data and DFT calculations and is characteristic of platinum complexes due to the heavy atom effect, which enhances the triplet state population and, consequently, the phosphorescence. Taking these facts into consideration as well as the same profile observed in all cases, the observed emission can be attributed to ${ }^{3} \mathrm{IL}$ that can be mixed with ${ }^{3} \mathrm{MLCT}$ transitions, involving the cyclometalated ligand. The value of the obtained lifetimes for the $\mathrm{Pt}-\mathrm{Ar}$ complexes, in the range 430-580 ns (Table 2), supports a triplet origin where the $\mathrm{T}_{1} \rightarrow \mathrm{S}_{0}$ transition become significantly allowed by the presence of the enhanced spin orbit coupling induced by $\mathrm{Pt}$ metal atom.

The phosphorescence quantum yields are lower than those for other cyclometalated $\mathrm{Pt}\left[\mathrm{C}^{\wedge} \mathrm{N}^{\wedge} \mathrm{N}\right]$ complexes reported in the literature and it may be ascribed to the more flexible imine ligand in comparison with the more rigid aromatic $\mathrm{Pt}$ $\left[\mathrm{C}^{\wedge} \mathrm{N}^{\wedge} \mathrm{N}\right]$ compounds. $^{15}$

ns-Transient Absorption. Time-resolved transient absorption spectra in the ns- and fs-TA were recorded in order to get further insights into the characteristics of the excited states formed. The transient triplet-triplet absorption spectra recorded by laser flash photolysis at $355 \mathrm{~nm}$ (ns-TA) of degassed acetonitrile solutions of the $\mathrm{Pt}-\mathrm{Ar}$ derivatives, in addition to ground-state depletion (in the 380-410 nm range), present intense broad triplet-triplet absorption bands ranging between 420 and $700 \mathrm{~nm}$; see Figure 3. Inspection of the spectra and the data summarized in Table 1 shows that the transient triplet-triplet wavelength maxima are basically constant for the five platinum-alkynyl cyclometalated compounds $2 \mathrm{a}-\mathbf{e}$, ranging from 490 to $540 \mathrm{~nm}$, thus showing that the triplet state is much more localized and essentially corresponding to a chromophore unit which is the basic structure of the $\mathrm{Pt}-\mathrm{Cl}(\mathbf{1})$. Moreover, triplet lifetimes, $\tau_{\mathrm{T}}$, in the 630-1200 ns range were found for the $\mathrm{Pt}-\mathrm{Ar}$ complexes (Table 2).

fs-Transient Absorption. fs-TA provides additional information on the excited-state formation and deactivation processes occurring with the $\mathrm{Pt}-\mathrm{Ar}$ complexes. The fs-TA data for $\mathrm{Pt}-\mathrm{Ar}$ compounds and $\mathrm{Pt}-\mathrm{Cl}$ spectra are dominated by strongly overlapped positive broad transient absorption bands in the 430-690 $\mathrm{nm}$ range, resulting from the convolution of the singlet excited state absorption $\mathrm{ESA}^{\left(S_{1}-S_{n}\right)}$ and the triplet excited state absorption, $\operatorname{ESA}^{\left(T_{1}-T_{n}\right)}$. Although a strong overlap is observed between these characteristic bands, the spectral resemblance of the bands observed at longer delay times in the fs-TA setup with the triplet-triplet absorption spectra obtained by ns-TA (see Figure 3), together with their longlived nature (kinetics traces not decaying within the fs-TA probe time window of $\sim 7.6 \mathrm{~ns}$ ), make us assign these to the excited state absorption, following intersystem crossing.

The best-fit results and representative kinetic traces of the characteristic transient absorption data are presented in Table 3 and Figure 4. In general, the experimental kinetic traces are well-fit with the sum of three exponentials: (i) a fast decay transient with values of $\sim 200 \mathrm{fs}$; (ii) one with values ranging from 0.5 to $3.8 \mathrm{ps}$; (ii) and a long-lived transient associated with the triplet state decay that was fixed in the analysis to the triplet state lifetime obtained from the nanosecond laser flash photolysis (Table 3).
Table 3. Intersystem Crossing Rate Constants ${k^{\prime}}_{\mathrm{ISC}}^{\mathrm{S}_{1} \sim \rightarrow \mathrm{T}_{1} a}$

$\begin{array}{ccc}\text { compound } & \tau^{\mathrm{S}_{1} \sim \rightarrow \mathrm{T}_{1}}(\mathrm{ps}) & k_{\mathrm{ISC}}^{\mathrm{S}_{1} \sim \mathrm{T}_{1}} \times 10^{11}(\mathrm{~s}) \\ \mathbf{1} & 0.5 & 9.4 \\ \mathbf{2 a} & 2.4 & 0.8 \\ \mathbf{2 b} & 3.2 & 0.3 \\ \mathbf{2 c} & 2.9 & 1.0 \\ \mathbf{2 d} & 1.1 & 1.1 \\ \mathbf{2 e} & 3.8 & 0.4\end{array}$

${ }^{a}$ Obtained from the results of the global fit analysis to the fs-TA data of the $\mathrm{Pt}-\mathrm{Ar}(\mathbf{2 a}-\mathbf{e})$ derivatives and $\mathrm{Pt}-\mathrm{Cl}(\mathbf{1})$ in acetonitrile solution at $293 \mathrm{~K}$.

The fastest transient lifetimes are in good agreement with solvent relaxation time of acetonitrile $(0.26 \mathrm{ps})$ and thus are assigned to the solvation dynamics, ${ }^{24}$ while the $0.5-3.8$ ps transient lifetimes are attributed to the decay of the singlet excited state which undergo rapid intersystem crossing $\left(\tau^{\mathrm{S}_{1} \sim \rightarrow \mathrm{T}_{1}}\right)$ to form the observed long-lived triplet state. The observed negative amplitude values associated with the $0.5-$ 3.8 ps transient lifetimes in the wavelength region where the $\mathrm{ESA}^{\left(T_{1}-T_{n}\right)}$ occurs, together with the concentration profiles of the time constants and the distinct rise of the long-lived, 438 ns, time constant (see Figure 4 insets) supports the triplet state being formed at the expense of the singlet excited state.

The kinetic data obtained from the fs-TA experiments are in good agreement with the luminescence lifetimes obtained with nanosecond resolution from the time-correlated single photon counting (ns-TCSPC) technique, thus showing the decay from a triplet state with the $\mathrm{T}_{1} \rightarrow \mathrm{S}_{0}$ transition becoming significantly allowed by the presence of the enhanced spinorbit coupling induced by $\mathrm{Pt}$ metal atom.

Additionally, the intersystem crossing (ISC) rate constants, $k_{\text {ISC }}^{\prime S_{1} \sim \rightarrow T_{1}}$, can be calculated (assuming a unitary singlet oxygen sensitization efficiency, $S_{\Delta}=\frac{\phi_{\mathrm{T}}}{\phi_{\Delta}}=1$ and therefore $\left.\phi_{\mathrm{T}} \cong \phi_{\Delta}\right)$ using the following

$$
k_{\mathrm{ISC}}^{\prime \mathrm{S}_{1} \sim \rightarrow \mathrm{T}_{1}}=\frac{\phi_{\mathrm{T}}}{\tau^{\mathrm{S}_{1} \sim \rightarrow \mathrm{T}_{1}}}
$$

where the decay time and the quantum yield were obtained in aerated (presence of $\mathrm{O}_{2}$ ) conditions. The obtained $k_{\mathrm{ISC}}^{\prime \mathrm{S}_{1} \sim \rightarrow \mathrm{T}_{1}}$ values support the fast triplet state formation in the $\mathrm{Pt}-\mathrm{Ar}$ (2a-e) complexes (Table 3).

Singlet Oxygen Production. The quantum yields of singlet oxygen sensitization for the $\mathrm{Pt}-\mathrm{Ar}(2 \mathbf{a}-\mathbf{e})$ and the precursor $\mathrm{Pt}-\mathrm{Cl}$ (1) were obtained by comparison of the nearinfrared phosphorescence signal of ${ }^{1} \mathrm{O}_{2}$ at $1270 \mathrm{~nm}$ with that obtained for $1 H$-phenalen-1-one as reference (Table 2). Measurements were carried out in aerated acetonitrile solutions of the $\mathrm{Pt}-\mathrm{Ar}$ complexes at room temperature.

It can be observed that the $\phi_{\Delta}$ values obtained for the alkynyl ligands are 4 times higher than those of the corresponding platinum complexes (see the comparison between $\mathrm{Pt}-\mathrm{Np}(\mathbf{2 d})$ and $\mathrm{Np}$ and Pt-Phen (2e) and Phen; Table S2). The obtained $\phi_{\Delta}$ values are more than 1 order of magnitude less than those measured for other platinum complexes recently reported in the literature ${ }^{25-27}$ and in the same order of the produced by recently reported $\mathrm{Pt}(\mathrm{II})$ complexes displaying efficient biological activity. 110,28,29 Thus, in this case, the flexibility of the current $\left[\mathrm{C}^{\wedge} \mathrm{N}^{\wedge} \mathrm{N}^{\prime}\right]$ ligand does not negatively affect (decrease) the resulting $\phi_{\Delta}$ values. 

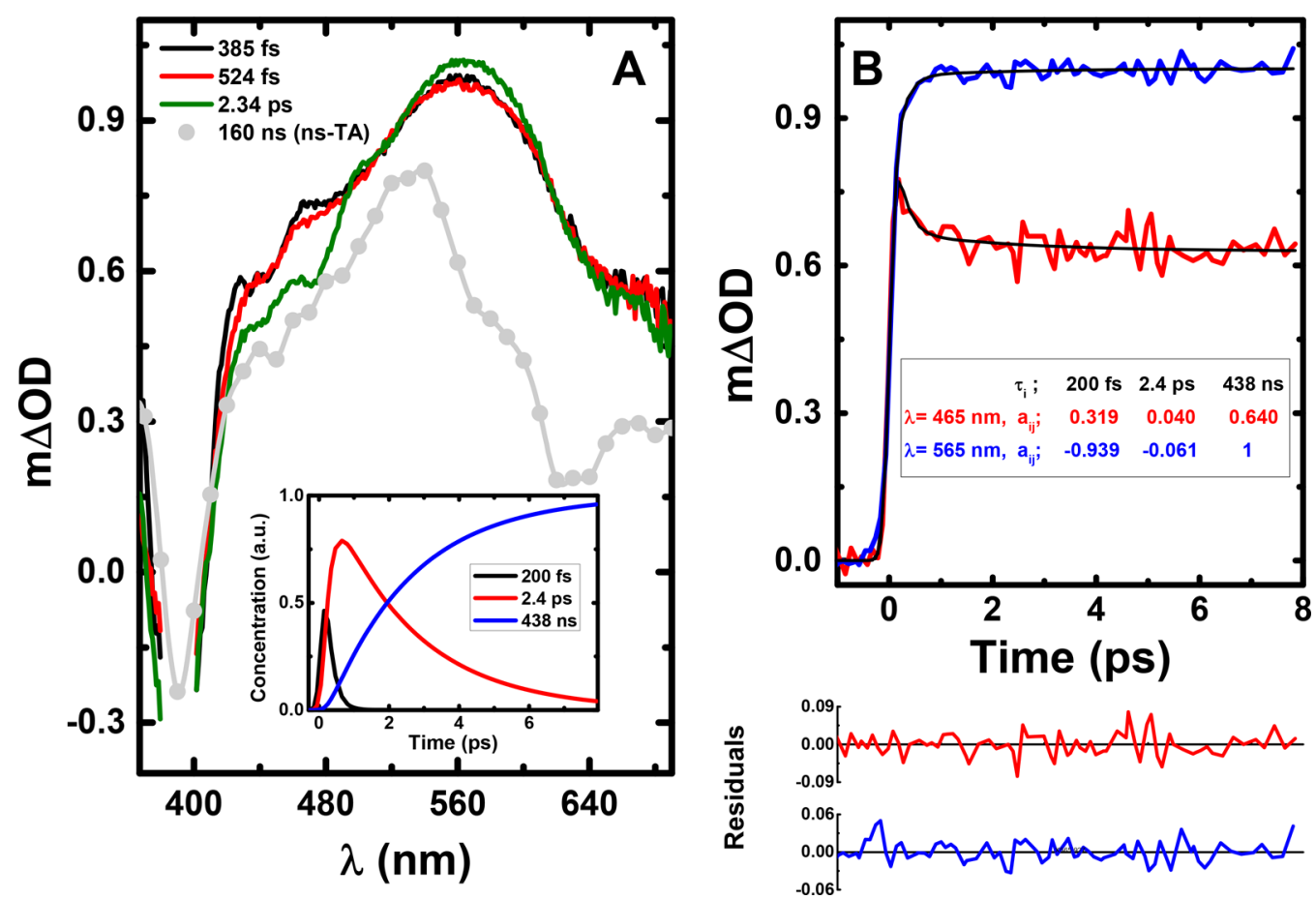

Figure 4. (A) Room-temperature femtosecond time-resolved transient absorption data for 2a collected in aerated acetonitrile solution with excitation at $390 \mathrm{~nm}$, together with the normalized ns-ms transient absorption spectra collected at $160 \mathrm{~ns}$ after laser flash photolysis. Inset: concentration profiles of the time constants obtained from the analysis to the transient absorption data are presented. fs-TA data in the spectral range 380-400 $\mathrm{nm}$ are not shown because it is disturbed by the scattered pump beam. (B) Representative kinetic traces with fits, lifetimes, and preexponential values resulting from the analysis of the transient absorption data; for a better judgment of the quality of the fits, the residuals are also shown.

It seems that the presence of the platinum heavy atom increases the efficiency of the intersystem crossing (ISC) from ${ }^{1} \mathrm{PS} *$ to ${ }^{3} \mathrm{PS} *(\mathrm{PS}=$ photosensitizer) and the long-lived triplet state of PS ( $\left.{ }^{3} \mathrm{PS} *\right)$ is a crucial component for the generation of ${ }^{1} \mathrm{O}_{2}{ }^{30}$ and for this, its importance is increasing in the last years and some examples have been found with very high ${ }^{1} \mathrm{O}_{2}$ photogeneration, being the $\mathrm{Pt}(\mathrm{II})$ species in the majority of the cases, attached to a macrocyclic structure (porphyrin or calixarene). ${ }^{2,9,31-34}$

From the values of the room-temperature phosphorescence quantum yields obtained in the presence, $\phi_{\mathrm{Ph}}$, and absence, $\phi_{\mathrm{Ph}}^{0}$, of oxygen, the following Stern-Volmer type relation can be retrieved, assuming that the effect of oxygen in the singlet lifetime is negligible (which is the case; see fs-TA data and Table 3 for details):

$$
\frac{\phi_{\mathrm{Ph}}^{0}}{\phi_{\mathrm{Ph}}}=1+\tau_{\mathrm{Ph}}^{\mathrm{o}} k_{\mathrm{ET}}
$$

where $\tau_{\mathrm{Ph}}^{\mathrm{o}}$ is the phosphorescence decay time obtained in deaerated conditions and $k_{\mathrm{ET}}$ is the pseudo-unimolecular rate constant of energy transfer that leads to the formation of singlet oxygen $\left(k_{\mathrm{ET}}=k^{\prime}\left[\mathrm{O}_{2}\right]\right.$ with $\left[\mathrm{O}_{2}\right]_{\text {acetonitrile }}=1.9 \times 10^{-3}$ $\left.\mathrm{mol} \mathrm{dm}{ }^{-3}\right) .35$ The values of $k_{\mathrm{ET}}$ calculated with eq 2 are summarized in Table 2.

Additionally, the following relation can be achieved from the singlet oxygen quantum yield, $\phi_{\Delta}$, and the $\phi_{\mathrm{Ph}}$ values obtained in the presence of oxygen:

$$
\frac{\phi_{\Delta}}{\phi_{\mathrm{Ph}}}=\frac{k_{\mathrm{ET}}}{k_{\mathrm{Ph}}}
$$

where $k_{\mathrm{Ph}}$ is the radiative rate constant for phosphorescence, easily obtained once $k_{\mathrm{ET}}$ is known. Finally, in aerated conditions the rate constant for intersystem crossing $\mathrm{T}_{1} \sim \rightarrow \mathrm{S}_{0}, k_{\mathrm{ISC}}^{\mathrm{T}_{1} \sim \rightarrow \mathrm{S}_{0}}$, can be calculated using the following equation

$$
k_{\mathrm{ISC}}^{\mathrm{T}_{1} \sim \rightarrow \mathrm{S}_{0}}=\frac{1}{\tau_{\mathrm{Ph}}}-k_{\mathrm{Ph}}-k_{\mathrm{ET}}
$$

or through

$$
k_{\mathrm{ISC}}^{\mathrm{T}_{\mathrm{i}} \sim \rightarrow \mathrm{S}_{0}}=\frac{1}{\tau_{\mathrm{Ph}}^{\mathrm{o}}}-k_{\mathrm{Ph}}
$$

From Table 2 it can be seen that in the absence of oxygen the dominant excited state deactivation pathway is the radiationless internal conversion process $\left(\phi_{\text {IC }}\right)$ both for $\mathrm{Pt}-$ $\mathrm{Cl}$ (1) and $\mathrm{Pt}-\mathrm{Ar}(\mathbf{2 a}-\mathbf{e})$.

Moreover, the phosphorescence quantum yields are very low even in the absence of oxygen. Interestingly, the pathway leading to singlet oxygen sensitization $\left(k_{\mathrm{ET}}\right)$ is highly competitive and always dominates with rate constants that are in some cases 4 times higher than internal conversion process, such as in the case of $\mathbf{2 a}$. That is, despite the fact that the ancillary ligand does not produce noticeable effects in the range where the triplet emission occurs, it may introduce a very significant impact in the production of singlet oxygen.

The radiative rate constant for the triplet emission is also significantly affected by the aromatic ancillary ligand. Despite the values of $k_{\mathrm{Ph}}$ always being more than 10 times lower than the internal conversion, there is a significant increase (3-4 times) in $k_{\mathrm{Ph}}$ for compounds $\mathbf{2 a}, \mathbf{2 b}, \mathbf{2 d}$, and $\mathbf{2 e}$ when compared with that of compound $\mathbf{1}$, which does not possess 
Table 4. Predicted Singlet and Triplet Transitions for All Complexes Including the Expected Wavelength and the Orbitals Involved in the Transition

\begin{tabular}{|c|c|c|}
\hline complex & singlet $\lambda_{\mathrm{em}}(\mathrm{nm})(f) /$ transition & triplet $\lambda_{\mathrm{em}}(\mathrm{nm}) /$ transition \\
\hline 1 & $\begin{array}{l}457(0.0174) \\
\text { LUMO } \rightarrow \text { HOMO }(88 \%)\end{array}$ & 629 LUMO $\rightarrow$ HOMO $(81 \%)$ \\
\hline $2 a$ & $\begin{array}{l}491(0.0008) \\
\text { LUMO } \rightarrow \text { HOMO }(98 \%)\end{array}$ & $\begin{array}{l}607 \text { LUMO } \rightarrow \text { HOMO-1 }(77 \%) \\
522 \text { LUMO } \rightarrow \text { HOMO }(97 \%)\end{array}$ \\
\hline $2 b$ & $\begin{array}{l}496(0.0012) \\
\text { LUMO } \rightarrow \text { HOMO }(98 \%)\end{array}$ & $\begin{array}{l}496 \text { LUMO } \rightarrow \text { HOMO-1 }(75 \%) \\
429 \text { LUMO } \rightarrow \text { HOMO }(96 \%)\end{array}$ \\
\hline $2 \mathrm{c}$ & $\begin{array}{l}507(0.0018) \\
\text { LUMO } \rightarrow \text { HOMO }(98 \%) \\
482(0.2675)\end{array}$ & $\begin{array}{l}608 \text { LUMO } \rightarrow \text { HOMO-1 }(76 \%) \\
548 \text { LUMO } \rightarrow \text { HOMO }(97 \%) \\
609 \text { LUMO } \rightarrow \text { HOMO-1 }(78 \%)\end{array}$ \\
\hline $2 \mathrm{~d}$ & LUMO $\rightarrow$ HOMO $(96 \%)$ & $\begin{array}{l}536 \text { LUMO }+1 \rightarrow \text { HOMO }(77 \%) \\
531 \text { LUMO } \rightarrow \text { HOMO }(90 \%)\end{array}$ \\
\hline $2 \mathrm{e}$ & $\begin{array}{l}514(0.0226) \\
\text { LUMO } \rightarrow \text { HOMO }(96 \%)\end{array}$ & $\begin{array}{l}608 \text { LUMO } \rightarrow \text { HOMO-1 }(75 \%) \\
591 \text { LUMO }+1 \rightarrow \text { HOMO }(88 \%) \\
550 \text { LUMO } \rightarrow \text { HOMO }(96 \%)\end{array}$ \\
\hline
\end{tabular}

the ancillary ligand. Only in the case of the thiophene ligand (2c) this effect is not observed.

Theoretical Studies. Theoretical calculations have been performed at DFT/B3LYP level to further understand the photophysical data. The minimum energy geometry conformation shows that in all cases the most stable expected conformation agrees with the X-ray crystal structures, displaying a perpendicular disposition between the aromatic rings of the chromophoric unit and the square-planar geometry around the cyclometalated unit (Figure S23) and validates the theoretical model.

As the spectra depends on the orientation of the aromatic group in the complex, calculations have been performed with the phenyl ring in $\mathbf{2 a}$ in parallel, oblique, or perpendicular disposition with respect to the metallacycle. As expected, the perpendicular disposition is the one that reproduces better the experimental data (Figure S24). Thus, this conformation has been chosen for the calculations of all the spectra in acetonitrile (Figures S25-S35 and Tables S3 and S4).

In all cases, the HOMO orbital is located at the Pt-Alkynylchromophoric unit. The closest occupied orbitals HOMO-1 and $\mathrm{HOMO}-2$ are located at the $\mathrm{Pt}-\mathrm{C} \equiv \mathrm{C}$ and aryl ring of the cyclometalated ligand, while HOMO-3 is mainly located at the metal. The lowest unoccupied molecular orbital, LUMO, is centered on the $\pi^{*}$ orbital of the phenyl ring of the $\mathrm{C}^{\wedge} \mathrm{N}$ ligand of the square-planar metallacycle. Thus, the lowest energy absorption transitions are assigned to ${ }^{1}$ LLCT $(\mathrm{C} \equiv \mathrm{C}$ $\left.\rightarrow \mathrm{C}^{\wedge} \mathrm{N}\right) /{ }^{1} \mathrm{MLCT}$ transitions.

There are several high-energy transitions between 260 and $290 \mathrm{~nm}$. The most intense $(262 \mathrm{~nm}$ with $f=0.24$ in the case of 2a) corresponds mainly to a $\mathrm{HOMO} \rightarrow \mathrm{LUMO}+4$ transition. Both orbitals are mainly centered in the alkyne group, with a small contribution from the d-orbitals of the metal, and in the case of LUMO+4, also from the cyclometalated fragment, so they can be mainly regarded as $\pi-\pi^{*}$ IL transitions.

In order to rationalize the luminescence results, we have calculated the vertical energies corresponding to the transitions between the ground state and the first singlet (for fluorescence) or triplet (for phosphorescence) excited states, using in each case the optimized geometries of the corresponding excited states. Our calculations predict a triplet emission with transitions between the LUMO+1/LUMO to HOMO/HOMO-1 orbitals (see Table 4). The predicted wavelengths for triplet emission are in agreement with the experimental data being another evidence for phosphorescence instead of fluorescence decays.

It should be noted that HOMO-1 and HOMO present some contribution of both metal and alkynyl chromophore, while the LUMO is mainly located at the ligand from the metallacycle part of the molecule. For this reason, the observed transitions can be rationalized as a mixture of ${ }^{3} \mathrm{IL}$ and ${ }^{3} \mathrm{MLCT}$ transitions.

\section{CONCLUSIONS}

The synthesis and a comprehensive photophysical characterization was undertaken for five novel cyclometalated platinum(II) compounds ( $\mathrm{Pt}-\mathrm{Ar}, \mathbf{2 a}-\mathbf{e})$. The absorption, emission, and excitation spectra of $\mathrm{Pt}-\mathrm{Ar}$ complexes are very similar with the $\mathrm{Pt}-\mathrm{Cl}$ cyclometalated compound (1) resulting in ${ }^{1} \mathrm{LLCT}$ $/{ }^{1}$ MLCT transitions for the absorption transitions and ${ }^{3} \mathrm{IL}$ and ${ }^{3}$ MLCT transitions for the emission. DFT calculations have been an important tool to determine the orbitals involved in these transitions. Pt...Pt interactions are not involved in the photophysical properties of the compounds in agreement with the X-ray crystal structure resolved for three of the complexes. From different time-resolved (from fs to ns) spectroscopic techniques it is found that at room temperature the deactivation of the excited state leads to a fast formation of the $\mathrm{T}_{1}$ state which subsequently deactivates (phosphorescence). The excited state is found to be mainly located in the cyclometalated platinum chromophore unit. The formed triplet state of precursor $\mathbf{1}$ and the corresponding $\mathrm{Pt}-\mathrm{Ar}$ derivatives has been measured and is found to efficiently sensitize molecular oxygen with values ranging from 11 to $47 \%$.

\section{EXPERIMENTAL SECTION}

General. All solvents used were spectroscopic-grade or its equivalent. Acetonitrile was purchased from Sigma-Aldrich. Deoxygenation of the solutions was done by bubbling with a stream of argon or nitrogen for approximately $20 \mathrm{~min}$ in a device elsewhere described. ${ }^{36}$ All measured solutions were freshly prepared (prior to the experiment).

All reagents were obtained from commercial sources and used as received. Ligand 4- $\mathrm{FC}_{6} \mathrm{H}_{4} \mathrm{CHN}\left(\mathrm{CH}_{2}\right)_{2} \mathrm{~N}\left(\mathrm{CH}_{3}\right)_{2}$ (L) and compound $\left[\operatorname{PtCl}\left\{\left(\mathrm{CH}_{3}\right)_{2} \mathrm{~N}\left(\mathrm{CH}_{2}\right)_{2} \mathrm{~N}=\mathrm{CH}\left(4-\mathrm{FC}_{6} \mathrm{H}_{3}\right)\right\}\right]$ (1) were prepared as reported elsewhere. ${ }^{11}$

Physical Measurements. Electrospray mass spectra were carried out at the Unitat d'Espectrometria de Masses (Universitat de Barcelona) using a LC/MSD-TOF spectrometer using $\mathrm{H}_{2} \mathrm{O}-$ 
$\mathrm{CH}_{3} \mathrm{CN} \mathrm{1:1}$ to introduce the sample. IR spectra were recorded in $\mathrm{KBr}$ dispersion on a FT-IR 520 Nicolet spectrophotometer. NMR spectra were carried out in $\mathrm{CDCl}_{3}$ at the Unitat de $\mathrm{RMN}$ of the Universitat de Barcelona using a Mercury 400 spectrometer $\left({ }^{1} \mathrm{H}, 400 \mathrm{MHz} ;{ }^{19} \mathrm{~F}\right.$, $376.5 \mathrm{MHz})$. Chemical shifts are given in $\delta$ values (ppm) relative to TMS $\left({ }^{1} \mathrm{H}\right)$ or $\mathrm{CFCl}_{3}\left({ }^{19} \mathrm{~F}\right)$ and coupling constants $J$ are given in $\mathrm{Hz}$. Numbering schemes for the compounds characterized are displayed in Scheme 1 . Absorption spectra were obtained in a $5 \mathrm{~mm}$ or $10 \mathrm{~mm}$ quartz cuvette in acetonitrile on a Cary 5000 UV-vis-NIR or Shimadzu UV-2450 spectrophotometer. The emission spectra of the compounds in solution were obtained in fluorescence quartz cuvette of 5 or $10 \mathrm{~mm}$ path length, using a Horiba-Jobin-Vonn Fluorolog 3.22 or Fluoromax spectrometers. Phosphorescence spectra and decays were recorded with the D1934 unit of Fluoromax 3.22 spectrometer. All the fluorescence and phosphorescence spectra were corrected for the wavelength response of the system with the appropriate correction files obtained for the instrument. Microanalyses were carried out at the Centres Cientifics i Tecnologics (Universitat de Barcelona). ${ }^{11,37}$

Emission Quantum Yield Determination and Laser Flash Photolysis Experiments. All measured solutions were degassed using a cuvette specially designed and described elsewhere for 20-30 min with $\mathrm{N}_{2}$ or $\mathrm{Ar}^{36}{ }^{36}$ Emission quantum yields were measured with a Hamamatsu Quantaurus QY absolute photoluminescence quantum yield spectrometer model C11437 (integration sphere). Transient absorption spectra were measured using a flash photolysis setup composed of a LKS 60 ns laser photolysis spectrometer from Applied Photophysics, pumped with third harmonic, $355 \mathrm{~nm}$, of a Spectra Physics Quanta-Ray Nd:YAG laser. The transient spectra were obtained by monitoring the optical density change at 5-10 nm intervals, averaging at least 10 decays at each wavelength.

Singlet Oxygen Yields. Room-temperature singlet oxygen NIR phosphorescence was detected using a Hamamatsu R5509-42 photomultiplier in the Applied Photophysics laser flash photolysis apparatus described above. A Newport RG1000 filter was used to eliminate the harmonic contribution of sensitizer emission from the infrared signal. The singlet oxygen formation quantum yields were determined by plotting the photosensitized singlet oxygen phosphorescence intensity at $1270 \mathrm{~nm}$ of optically matched aerated solutions of the samples and reference compound as a function of the laser energy $^{38}$ and comparing the slopes using eq 6 :

$$
\phi_{\Delta}{ }^{\mathrm{cp}}=\frac{\text { slope }^{\mathrm{cp}}}{\text { slope }^{\text {ref }}} \cdot \phi_{\Delta}{ }^{\text {ref }}
$$

with $\phi_{\Delta}^{\text {ref }}$ being the singlet oxygen formation quantum yield of the reference compound. $1 \mathrm{H}$-Phenal-1-one in acetonitrile $\left(\phi_{\Delta}=0.98\right)$ was used as the standard.

TCSPC. Phosphorescence decays were obtained either in aerated or degassed acetonitrile solutions and were measured with two different custom-built time-correlated single-photon counting equipment (TCSPC). For the $\mathrm{Pt}-\mathrm{Ar}(\mathbf{2 a}-\mathbf{e})$ and $\mathrm{Pt}-\mathrm{Cl}$ (1) compounds, nsTCSPC was carried out as elsewhere reported except that a nanoLED (excitation at $373 \mathrm{~nm}$ ) IBH was used as the excitation source. ${ }^{39}$ Deconvolution of the phosphorescence decay curves was performed using the modulating function method, as implemented by G. Striker in the SAND program. ${ }^{40}$

fs-TA. The experimental setup for ultrafast spectroscopic and kinetic measurements was described elsewhere ${ }^{41}$ and consists of a broadband HELIOS pump-probe fs-TA (350-1600 nm) spectrometer from Ultrafast Systems equipped with an amplified femtosecond Spectra-Physics Solstice-100F laser $(800 \mathrm{~nm}$ central wavelength displaying a pulse width of $128 \mathrm{fs}$ at $1 \mathrm{kHz}$ repetition rate) that is coupled with a Spectra-Physics TOPAS Prime F optical parametric amplifier (195-22 $000 \mathrm{~nm}$ ) for pulse pump generation. Probe light in the UV range was generated by passing a small portion of the $800 \mathrm{~nm}$ light from the Solstice-100F laser through a computerized optical delay (with a time window up to $8 \mathrm{~ns}$ ) and focusing in a vertical translating $\mathrm{CaF}_{2}$ crystal to generate a white-light continuum (350$750 \mathrm{~nm}$ ). All measurements were obtained in a $2 \mathrm{~mm}$ quartz cuvette with absorptions lower than 0.3 at the pump excitation wavelength. The instrumental response function of the system was assumed to be equal to that of the pump-probe cross-correlation determined from the measurement of the instantaneous stimulated Raman signal from the pure solvent (in an analogous $2 \mathrm{~mm}$ cuvette). Typical values for the IRF of the system were found to be better than $250 \mathrm{fs}$. The solutions were stirred during the experiments or kept moving using a motorized translating sample holder in order to avoid photodegradation. The spectral chirp of the data was corrected using Surface Xplorer PRO program from Ultrafast Systems. Global analysis of the data (using a sequential model) was performed after single value decomposition using Glotaran software. ${ }^{42}$

X-ray Diffraction. Single crystals suitable for X-ray diffraction analysis were grown for $\mathbf{2 b}, \mathbf{2 c}$, and $\mathbf{2 d}$ by slow diffusion of hexane in a dichloromethane solution of the compounds. The crystal data and experimental details for the data collections are given below. Singlecrystal X-ray data for $\mathbf{2 b}, \mathbf{2 c}$, and $\mathbf{2 d}$ were collected at $170 \mathrm{~K}$ on a Bruker-Nonius KappaCCD diffractometer with an APEX-II detector with graphite-monochromatised $\mathrm{Mo}-\mathrm{K} \alpha(\lambda=0.71073 \AA)$ radiation. Data collection was carried out using the program COLLECT, ${ }^{43}$ with data reduction performed using HKL DENZO and SCALEPACK, ${ }^{44}$ with intensities absorption corrected using SADABS. ${ }^{45}$ All structures were solved using ShelXT, ${ }^{46}$ and refined by full-matrix least-squares on $F^{2}$ using SHELXL ${ }^{47}$ in the OLEX2 program package. ${ }^{48}$ Anisotropic displacement parameters were assigned to non- $\mathrm{H}$ atoms. Positional disorder in the structures was treated by gently restraining geometric and anisotropic displacement parameters. All hydrogen atoms were refined using riding models with $U_{\mathrm{eq}}(\mathrm{H})$ of $1.5 U_{\mathrm{eq}}(\mathrm{C})$. CCDC 1970145-1970147 contain the supplementary crystallographic data for this paper. These data can be obtained free of charge via http:// www.ccdc.cam.ac.uk/conts/retrieving.html (or from the CCDC, 12 Union Road, Cambridge CB2 1EZ, UK; Fax: + 441223 336033; Email: deposit@ccdc.cam.ac.uk). Crystallographic details are given in Table S1.

Theoretical Calculations. DFT calculations have been performed using the Q-Chem ${ }^{49}$ software implemented in Spartan'18, ${ }^{50}$ with the B3LYP ${ }^{51,52}$ functional and the following basis set: 6$31 G^{*}, 53,54$ including polarization for non-hydrogen atoms, for $\mathrm{C}, \mathrm{H}$, $\mathrm{N}$, and $\mathrm{Cl}$ and LANL2DZ ${ }^{55}$ for Pt. Solvation effects have been included using the CPCM method. ${ }^{56}$

$\mathrm{UV} /$ vis transitions have been calculated at the TD-DFT level using the same functional and basis set; this methodology has provided satisfactory results in our previous work. ${ }^{57}$ To estimate the emission spectra, we have optimized the geometries corresponding to the first singlet (for fluorescence) and triplet (for phosphorescence) states and calculated the transitions between the ground state and the excited states using the corresponding excited state geometries.

Preparation of the Complexes. $\left[\mathrm{Pt}(\mathrm{C} \equiv \mathrm{CPh})\left\{\left(\mathrm{CH}_{3}\right)_{2} \mathrm{~N}\right.\right.$ $\left.\left(\mathrm{CH}_{2}\right)_{2} \mathrm{~N}=\mathrm{CH}\left(4-\mathrm{FC}_{6} \mathrm{H}_{3}\right)\right\}$ ] (2a) was obtained from the reaction of $0.103 \mathrm{~g}(0.243 \mathrm{mmol})$ of $\left[\mathrm{PtCl}\left\{\left(\mathrm{CH}_{3}\right)_{2} \mathrm{~N}\left(\mathrm{CH}_{2}\right)_{2} \mathrm{~N}=\mathrm{CH}(4-\right.\right.$ $\left.\left.\left.\mathrm{FC}_{6} \mathrm{H}_{3}\right)\right\}\right]$ (1), $0.025 \mathrm{~g}(0.249 \mathrm{mmol})$ of phenylacetylene, $0.010 \mathrm{~g}$ $(0.053 \mathrm{mmol})$ of $\mathrm{CuI}$, and $0.061 \mathrm{~g}(0.744 \mathrm{mmol})$ of sodium acetate in $\mathrm{CH}_{2} \mathrm{Cl}_{2} /$ methanol $(10: 1)$. The mixture was stirred at room temperature under nitrogen and protected from light for $48 \mathrm{~h}$. The solvent was removed under vacuum, and the residue was treated with hexane. The orange solid was filtered and dried under vacuum. Yield: $0.091 \mathrm{~g}(76 \%) .{ }^{1} \mathrm{H}$ NMR $\left(\mathrm{CDCl}_{3}, 400 \mathrm{MHz}\right): \delta 8.32\left[\mathrm{~s}, 1 \mathrm{H},{ }^{3} J(\mathrm{Pt}-\right.$ $\left.\mathrm{H})=81.2, \mathrm{H}^{\mathrm{d}}\right], 7.55\left[\mathrm{dd}, 1 \mathrm{H},{ }^{3} J(\mathrm{~F}-\mathrm{H})=9.6,{ }^{4} J(\mathrm{H}-\mathrm{H})=2.3,{ }^{3} J(\mathrm{Pt}-\right.$ $\left.\mathrm{H})=70.2, \mathrm{H}^{\mathrm{a}}\right], 7.48\left[\mathrm{~d}, 2 \mathrm{H},{ }^{3} \mathrm{~J}(\mathrm{H}-\mathrm{H})=7.1, \mathrm{H}^{\mathrm{Ph}}\right], 7.22-7.24[\mathrm{~m}, 3 \mathrm{H}$, $\left.\mathrm{H}^{\mathrm{c}, \mathrm{Ph}}\right], 7.15\left[\mathrm{t}, 1 \mathrm{H},{ }^{3} \mathrm{~J}(\mathrm{H}-\mathrm{H})=7.4, \mathrm{H}^{\mathrm{Ph}}\right], 6.66\left[\mathrm{td}, 1 \mathrm{H},{ }^{3} \mathrm{~J}(\mathrm{~F}-\mathrm{H})=\right.$ $\left.{ }^{3} J(\mathrm{H}-\mathrm{H})=8.8,{ }^{4} J(\mathrm{H}-\mathrm{H})=2.6, \mathrm{H}^{\mathrm{b}}\right], 4.01\left[\mathrm{t},{ }^{3} \mathrm{~J}(\mathrm{H}-\mathrm{H})=11.7,2 \mathrm{H}\right.$, $\left.\mathrm{H}^{\mathrm{e}}\right], 3.15\left[\mathrm{t}, 2 \mathrm{H},{ }^{3} \mathrm{~J}(\mathrm{H}-\mathrm{H})=6.0 \mathrm{~Hz}, \mathrm{H}^{\mathrm{f}}\right], 3.06\left[\mathrm{~s}, 6 \mathrm{H},{ }^{3} J(\mathrm{Pt}-\mathrm{H})=\right.$ 20.2, $\mathrm{H}^{\mathrm{g}}$ ]. ${ }^{19} \mathrm{~F}$ NMR $\left(\mathrm{CDCl}_{3}, 376.5 \mathrm{MHz}\right): \delta-108.44$ [s, 1F]. MS$\mathrm{ESI}^{+}: m / z 490.12[\mathrm{M}+\mathrm{H}]^{+}$. IR: $v 2097.10(\mathrm{C} \equiv \mathrm{C})$. Anal. Found (calcd for $\mathrm{C}_{19} \mathrm{H}_{19} \mathrm{FN}_{2} \mathrm{Pt} \cdot 0.5 \mathrm{CH}_{2} \mathrm{Cl}_{2}$ ): C 44.86 (44.03); $\mathrm{H} 3.52$ (3.79); N $5.24(5.27)$.

$\left[\mathrm{Pt}(\mathrm{C} \equiv \mathrm{CPh}-\mathrm{F})\left\{\left(\mathrm{CH}_{3}\right)_{2} \mathrm{~N}\left(\mathrm{CH}_{2}\right)_{2} \mathrm{~N}=\mathrm{CH}\left(4-\mathrm{FC}_{6} \mathrm{H}_{3}\right)\right\}\right] \quad(\mathbf{2 b})$ was obtained as an orange solid using the same procedure from $0.102 \mathrm{~g}$ $(0.241 \mathrm{mmol})$ of $\left[\mathrm{PtCl}\left\{\left(\mathrm{CH}_{3}\right)_{2} \mathrm{~N}\left(\mathrm{CH}_{2}\right)_{2} \mathrm{~N}=\mathrm{CH}\left(4-\mathrm{FC}_{6} \mathrm{H}_{3}\right)\right\}\right]$ (1), $0.030 \mathrm{~g}(0.249 \mathrm{mmol})$ of 1-ethynyl-4-fluorobenzene, $0.010 \mathrm{~g}(0.053$ 
$\mathrm{mmol})$ of CuI, and $0.063 \mathrm{~g}(0.768 \mathrm{mmol})$ of sodium acetate. Yield: $0.070 \mathrm{~g}(57 \%) .{ }^{1} \mathrm{H} \mathrm{NMR}\left(\mathrm{CDCl}_{3}, 400 \mathrm{MHz}\right): \delta 8.34\left[\mathrm{~s}, 1 \mathrm{H},{ }^{3} J(\mathrm{Pt}-\right.$ $\left.\mathrm{H})=81.3, \mathrm{H}^{\mathrm{d}}\right], 7.53\left[\mathrm{dd}, 1 \mathrm{H},{ }^{3} \mathrm{~J}(\mathrm{~F}-\mathrm{H})=9.4,{ }^{4} \mathrm{~J}(\mathrm{H}-\mathrm{H})=2.7,{ }^{3} \mathrm{~J}(\mathrm{Pt}-\right.$ $\left.\mathrm{H})=71.1, \mathrm{H}^{\mathrm{a}}\right], 7.43\left[\mathrm{dd}, \mathrm{J}=8.9,5.5 \mathrm{~Hz}, 2 \mathrm{H}, \mathrm{H}^{\mathrm{Ph}-\mathrm{F}}\right], 7.23[\mathrm{~m}, 1 \mathrm{H}$, $\left.\mathrm{H}^{\mathrm{c}}\right], 6.93\left[\mathrm{t}, 2 \mathrm{H},{ }^{3} \mathrm{~J}(\mathrm{~F}-\mathrm{H})={ }^{3} \mathrm{~J}(\mathrm{H}-\mathrm{H})=8.9, \mathrm{H}^{\mathrm{Ph}-\mathrm{F}}\right], 6.67[\mathrm{td}, 1 \mathrm{H}$, $\left.{ }^{3} J(\mathrm{~F}-\mathrm{H})={ }^{3} J(\mathrm{H}-\mathrm{H})=8.6,{ }^{4} J(\mathrm{H}-\mathrm{H})=2.6, \mathrm{H}^{\mathrm{b}}\right], 4.03\left[\mathrm{t}, 2 \mathrm{H},{ }^{3} J(\mathrm{H}-\right.$ $\left.\mathrm{H})=5.9, \mathrm{H}^{\mathrm{e}}\right], 3.15\left[\mathrm{t}, 2 \mathrm{H},{ }^{3} \mathrm{~J}(\mathrm{H}-\mathrm{H})=6.0, \mathrm{H}^{\mathrm{f}}\right], 3.04\left[\mathrm{~s}, 6 \mathrm{H},{ }^{3} J(\mathrm{Pt}-\mathrm{H})\right.$ $\left.=20.2, \mathrm{H}^{\mathrm{g}}\right] .{ }^{19} \mathrm{~F}$ NMR $\left(\mathrm{CDCl}_{3}, 376.5 \mathrm{MHz}\right): \delta-103.98[\mathrm{~s}, 1 \mathrm{~F}]$, $-115.55\left[\mathrm{~s}, 1 \mathrm{~F}, \mathrm{~F}^{\mathrm{a}}\right.$ ]. MS-ESI ${ }^{+}: m / z 508.12[\mathrm{M}+\mathrm{H}]^{+}$. IR: $v 2100.26$ $(\mathrm{C} \equiv \mathrm{C})$. Anal. Found (calcd for $\mathrm{C}_{19} \mathrm{H}_{18} \mathrm{~F}_{2} \mathrm{~N}_{2} \mathrm{Pt} \cdot 0.5 \mathrm{CH}_{2} \mathrm{Cl}_{2}$ ): $\mathrm{C} 42.59$ (42.59); H 3.29 (3.48); N 5.12 (5.09).

$\left[\mathrm{Pt}(\mathrm{C} \equiv \mathrm{CThio})\left\{\left(\mathrm{CH}_{3}\right)_{2} \mathrm{~N}\left(\mathrm{CH}_{2}\right)_{2} \mathrm{~N}=\mathrm{CH}\left(4-\mathrm{FC}_{6} \mathrm{H}_{3}\right)\right\}\right]$ (2c) was obtained as an orange solid using the same procedure from $0.099 \mathrm{~g}$ $(0.243 \mathrm{mmol})$ of $\left[\mathrm{PtCl}\left\{\left(\mathrm{CH}_{3}\right)_{2} \mathrm{~N}\left(\mathrm{CH}_{2}\right)_{2} \mathrm{~N}=\mathrm{CH}\left(4-\mathrm{FC}_{6} \mathrm{H}_{3}\right)\right\}\right]$ (1), $0.027 \mathrm{~g}(0.249 \mathrm{mmol})$ of 3-ethynyltiophene, $0.010 \mathrm{~g}(0.053 \mathrm{mmol})$ of CuI, and $0.060 \mathrm{~g}(0.731 \mathrm{mmol})$ of sodium acetate. Yield: $0.086 \mathrm{~g}$ (74\%). ${ }^{1} \mathrm{H}$ NMR $\left(\mathrm{CDCl}_{3}, 400 \mathrm{MHz}\right): \delta 8.35\left[\mathrm{~s}, 1 \mathrm{H},{ }^{3} J(\mathrm{Pt}-\mathrm{H})=80.9\right.$, $\left.\mathrm{H}^{\mathrm{d}}\right], 7.56\left[\mathrm{dd}, 1 \mathrm{H},{ }^{3} \mathrm{~J}(\mathrm{~F}-\mathrm{H})=9.6,{ }^{4} \mathrm{~J}(\mathrm{H}-\mathrm{H})=2.7,{ }^{3} \mathrm{~J}(\mathrm{Pt}-\mathrm{H})=70.7\right.$, $\mathrm{H}^{\mathrm{a}}$ ], $7.24\left[\mathrm{~m}, 2 \mathrm{H}, \mathrm{H}^{\mathrm{c}, \text { Tioph }}\right], 7.19\left[\mathrm{dd}, 1 \mathrm{H},{ }^{3} J(\mathrm{H}-\mathrm{H})=4.9,{ }^{3} \mathrm{~J}(\mathrm{H}-\mathrm{H})=\right.$ 3.0, $\mathrm{H}^{\text {Tioph }}$ ], $7.14\left[\mathrm{dd}, 1 \mathrm{H},{ }^{3} J(\mathrm{H}-\mathrm{H})=4.9,{ }^{3} \mathrm{~J}(\mathrm{H}-\mathrm{H})=1.1, \mathrm{H}^{\text {Tioph }}\right.$, $6.66\left[\mathrm{td}, 1 \mathrm{H},{ }^{3} \mathrm{~J}(\mathrm{~F}-\mathrm{H})={ }^{3} J(\mathrm{H}-\mathrm{H})=8.6,{ }^{4} J(\mathrm{H}-\mathrm{H})=2.5, \mathrm{H}^{\mathrm{b}}\right], 4.03$ $\left[\mathrm{t}, 2 \mathrm{H},{ }^{3} \mathrm{~J}(\mathrm{H}-\mathrm{H})=6.4, \mathrm{H}^{\mathrm{e}}\right], 3.14\left[\mathrm{t}, 2 \mathrm{H},{ }^{3} \mathrm{~J}(\mathrm{H}-\mathrm{H})=6.0, \mathrm{H}^{\mathrm{f}}\right], 3.04[\mathrm{~s}$, $\left.6 \mathrm{H},{ }^{3} \mathrm{~J}(\mathrm{Pt}-\mathrm{H})=20.5, \mathrm{H}^{\mathrm{g}}\right] .{ }^{19} \mathrm{~F}$ NMR $\left(\mathrm{CDCl}_{3}, 376.5 \mathrm{MHz}\right): \delta$ $-104.17[\mathrm{~s}, 1 \mathrm{~F}]$. MS-ESI ${ }^{+}: m / z 496.08[\mathrm{M}+\mathrm{H}]^{+}$. IR: $v 2104.33$ (C三C). Anal. Found (calcd for $\mathrm{C}_{17} \mathrm{H}_{17} \mathrm{FN}_{2} \mathrm{PtS} \cdot 0.5 \mathrm{CH}_{2} \mathrm{Cl}_{2}$ ): $\mathrm{C} 39.07$ (39.52); H 3.34 (3.37); N 5.31 (5.21); S 5.77 (5.96).

$\left[\mathrm{Pt}(\mathrm{C} \equiv \mathrm{CNaph})\left\{\left(\mathrm{CH}_{3}\right)_{2} \mathrm{~N}\left(\mathrm{CH}_{2}\right)_{2} \mathrm{~N}=\mathrm{CH}\left(4-\mathrm{FC}_{6} \mathrm{H}_{3}\right)\right\}\right]$ (2d) was obtained as an orange solid using the same procedure from $0.051 \mathrm{~g}$ $(0.120 \mathrm{mmol})$ of $\left[\mathrm{PtCl}\left\{\left(\mathrm{CH}_{3}\right)_{2} \mathrm{~N}\left(\mathrm{CH}_{2}\right)_{2} \mathrm{~N}=\mathrm{CH}\left(4-\mathrm{FC}_{6} \mathrm{H}_{3}\right)\right\}\right]$ (1), $0.019 \mathrm{~g}(0.125 \mathrm{mmol})$ of 2-ethynylnaphthalene, $0.005 \mathrm{~g}(0.026 \mathrm{mmol})$ of CuI, and $0.029 \mathrm{~g}(0.359 \mathrm{mmol})$ of sodium acetate. Yield: $0.050 \mathrm{~g}$ (77\%). ${ }^{1} \mathrm{H}$ NMR $\left(\mathrm{CDCl}_{3}, 400 \mathrm{MHz}\right): \delta 8.36\left[\mathrm{~s}, 1 \mathrm{H},{ }^{3} J(\mathrm{Pt}-\mathrm{H})=79.5\right.$, $\left.\mathrm{H}^{\mathrm{d}}\right], 7.92\left[\mathrm{~s}, 1 \mathrm{H}, \mathrm{H}^{\mathrm{Naph}}\right] ; 7.74\left[\mathrm{t}, 2 \mathrm{H},{ }^{3} \mathrm{~J}(\mathrm{H}-\mathrm{H})=6.7, \mathrm{H}^{\mathrm{Naph}}\right], 7.70[\mathrm{~d}$, $\left.1 \mathrm{H},{ }^{3} J(\mathrm{H}-\mathrm{H})=8.4, \mathrm{H}^{\mathrm{Naph}}\right], 7.64\left[\mathrm{~d}, 1 \mathrm{H},{ }^{3} J(\mathrm{~F}-\mathrm{H})=10.4, \mathrm{H}^{\mathrm{a}}\right], 7.57$ $\left[\mathrm{d}, 1 \mathrm{H},{ }^{3} \mathrm{~J}(\mathrm{H}-\mathrm{H})=8.4, \mathrm{H}^{\mathrm{Naph}}\right], 7.39\left[\mathrm{~m}, 2 \mathrm{H}, \mathrm{H}^{\mathrm{Naph}}\right], 7.26[\mathrm{~m}, 1 \mathrm{H}$, $\left.\mathrm{H}^{\mathrm{c}}\right], 6.68\left[\mathrm{t}, 1 \mathrm{H},{ }^{3} \mathrm{~J}(\mathrm{~F}-\mathrm{H})={ }^{3} \mathrm{~J}(\mathrm{H}-\mathrm{H})=8.8, \mathrm{H}^{\mathrm{b}}\right], 4.04\left[\mathrm{t}, 2 \mathrm{H},{ }^{3} \mathrm{~J}(\mathrm{H}-\right.$ $\left.\mathrm{H})=6.2, \mathrm{H}^{\mathrm{e}}\right], 3.17\left[\mathrm{t}, 2 \mathrm{H},{ }^{3} \mathrm{~J}(\mathrm{H}-\mathrm{H})=5.4, \mathrm{H}^{\mathrm{f}}\right], 3.10\left[\mathrm{~s}, 6 \mathrm{H},{ }^{3} \mathrm{~J}(\mathrm{Pt}-\right.$ $\left.\mathrm{H})=19.6, \mathrm{H}^{\mathrm{g}}\right] .{ }^{19} \mathrm{~F} \mathrm{NMR}\left(\mathrm{CDCl}_{3}, 376.5 \mathrm{MHz}\right): \delta-104.16[\mathrm{~s}, 1 \mathrm{~F}]$. MS-ESI ${ }^{+}: m / z 539.14[\mathrm{M}+\mathrm{H}]^{+}$. IR: $v 2099.88(\mathrm{C} \equiv \mathrm{C})$.

$\left[\mathrm{Pt}(\mathrm{C} \equiv \mathrm{CPhen})\left\{\left(\mathrm{CH}_{3}\right)_{2} \mathrm{~N}\left(\mathrm{CH}_{2}\right)_{2} \mathrm{~N}=\mathrm{CH}\left(4-\mathrm{FC}_{6} \mathrm{H}_{3}\right)\right\}\right] \quad$ (2e) was obtained as an orange solid using the same procedure from $0.052 \mathrm{~g}$ $(0.123 \mathrm{mmol})$ of $\left[\mathrm{PtCl}\left\{\left(\mathrm{CH}_{3}\right)_{2} \mathrm{~N}\left(\mathrm{CH}_{2}\right)_{2} \mathrm{~N}=\mathrm{CH}\left(4-\mathrm{FC}_{6} \mathrm{H}_{3}\right)\right\}\right]$ (1), $0.025 \mathrm{~g}(0.125 \mathrm{mmol})$ of 9-ethynylphenanthrene, $0.005 \mathrm{~g}(0.026$ $\mathrm{mmol})$ of $\mathrm{CuI}$, and $0.031 \mathrm{~g}(0.378 \mathrm{mmol})$ of sodium acetate. Yield: $0.061 \mathrm{~g}(84 \%) .{ }^{1} \mathrm{H}$ NMR $\left(\mathrm{CDCl}_{3}, 400 \mathrm{MHz}\right): \delta 8.81\left[\mathrm{~m}, 1 \mathrm{H}, \mathrm{H}^{\text {Phen }}\right]$, $8.65\left[\mathrm{~m}, 1 \mathrm{H}, \mathrm{H}^{\text {Phen }}\right], 8.61\left[\mathrm{~d},{ }^{3} \mathrm{~J}(\mathrm{H}-\mathrm{H})=7.8,1 \mathrm{H}, \mathrm{H}^{\text {Phen }}\right], 8.30[\mathrm{~s}, 1 \mathrm{H}$, $\left.{ }^{3} J(\mathrm{Pt}-\mathrm{H})=81.9, \mathrm{H}^{\mathrm{d}}\right], 7.96\left[\mathrm{~s}, 1 \mathrm{H}, \mathrm{H}^{\mathrm{Phen}}\right], 7.79\left[\mathrm{~d},{ }^{3} J(\mathrm{H}-\mathrm{H})=7.3\right.$, $\left.1 \mathrm{H}, \mathrm{H}^{\mathrm{a}}\right], 7.68\left[\mathrm{dd}, 1 \mathrm{H},{ }^{3} \mathrm{~J}(\mathrm{H}-\mathrm{H})=9.6,{ }^{4} \mathrm{~J}(\mathrm{H}-\mathrm{H})=2.3, \mathrm{H}^{\text {Phen }}\right], 7.63$ $\left[\mathrm{m}, 2 \mathrm{H}, \mathrm{H}^{\text {Phen }}\right], 7.55\left[\mathrm{~m}, 2 \mathrm{H}, \mathrm{H}^{\text {Phen }}\right], 7.26\left[\mathrm{~m}, 1 \mathrm{H}, \mathrm{H}^{\mathrm{c}}\right], 6.68[\mathrm{td}, 1 \mathrm{H}$, $\left.{ }^{3} J(\mathrm{~F}-\mathrm{H})={ }^{3} J(\mathrm{H}-\mathrm{H})=8.5,{ }^{4} J(\mathrm{H}-\mathrm{H})=2.6, \mathrm{H}^{\mathrm{b}}\right], 4.53\left[\mathrm{t}, 2 \mathrm{H},{ }^{3} \mathrm{~J}(\mathrm{H}-\right.$ $\left.\mathrm{H})=6.2, \mathrm{H}^{\mathrm{e}}\right], 3.18\left[\mathrm{t}, 2 \mathrm{H},{ }^{3} \mathrm{~J}(\mathrm{H}-\mathrm{H})=5.9, \mathrm{H}^{\mathrm{f}}\right], 3.12\left[\mathrm{~s}, 6 \mathrm{H},{ }^{3} \mathrm{~J}(\mathrm{Pt}-\right.$ $\left.\mathrm{H})=19.3, \mathrm{H}^{\mathrm{g}}\right] .{ }^{19} \mathrm{~F} \mathrm{NMR}\left(\mathrm{CDCl}_{3}, 376.5 \mathrm{MHz}\right): \delta-103.86[\mathrm{~s}, 1 \mathrm{~F}]$. MS-ESI ${ }^{+}: m / z 590.16[\mathrm{M}+\mathrm{H}]^{+}$. IR: $v 2078.10(\mathrm{C} \equiv \mathrm{C})$.

\section{ASSOCIATED CONTENT}

\section{SI Supporting Information}

The Supporting Information is available free of charge at https://pubs.acs.org/doi/10.1021/acs.inorgchem.0c00577.

${ }^{1} \mathrm{H}$ and ${ }^{19} \mathrm{~F}$ NMR and ESI-MS(+) spectra of the compounds. Absorption, emission, and excitation data. $\mathrm{X}$-ray crystal data (unit cell and packing, crystal data and refinement) of $\mathbf{2 b}, \mathbf{2 c}$, and $\mathbf{2 d}$. Representation of the minimum energy geometry conformation, orbitals and Cartesian coordinates involved in the transitions and calculated UV-visible spectra of the cyclometalated complexes (PDF)

\section{Accession Codes}

CCDC 1970145-1970147 contain the supplementary crystallographic data for this paper. These data can be obtained free of charge via www.ccdc.cam.ac.uk/data_request/cif, or by emailing data_request@ccdc.cam.ac.uk, or by contacting The Cambridge Crystallographic Data Centre, 12 Union Road, Cambridge CB2 1EZ, UK; fax: +44 1223336033.

\section{AUTHOR INFORMATION}

\section{Corresponding Authors}

Laura Rodríguez - Departament de Química Inorgànica $i$ Orgànica, Secció de Química Inorgànica and Institut de Nanociencia i Nanotecnologia (IN2UB), Universitat de Barcelona, E-08028 Barcelona, Spain; (1) orcid.org/00000003-1289-1587; Email: laura.rodriguez@qi.ub.es

J. Sérgio Seixas de Melo - University of Coimbra, Coimbra Chemistry Centre, Department of Chemistry, 3004-535 Coimbra, Portugal; ic orcid.org/0000-0001-9708-5079; Email: sseixas@ci.uc.pt

\section{Authors}

Ariadna Lázaro - Departament de Química Inorgànica $i$ Orgànica, Secció de Química Inorgànica and Institut de Nanociencia i Nanotecnologia (IN2UB), Universitat de Barcelona, E-08028 Barcelona, Spain

Carla Cunha - University of Coimbra, Coimbra Chemistry Centre, Department of Chemistry, 3004-535 Coimbra, Portugal

Ramon Bosque - Departament de Química Inorgànica $i$ Orgànica, Secció de Química Inorgànica, Universitat de Barcelona, E-08028 Barcelona, Spain

João Pina - University of Coimbra, Coimbra Chemistry Centre, Department of Chemistry, 3004-535 Coimbra, Portugal; (1) orcid.org/0000-0003-1848-1167

Jas S. Ward - Jyväskylä University of Applied Sciences, Department of Chemistry, 40014 Jyväskylä, Finland; (1) orcid.org/0000-0001-9089-9643

Khai-Nghi Truong - Jyväskylä University of Applied Sciences, Department of Chemistry, 40014 Jyväskylä, Finland

Kari Rissanen - Jyväskylä University of Applied Sciences, Department of Chemistry, 40014 Jyväskylä, Finland; (1) orcid.org/0000-0002-7282-8419

João Carlos Lima - LAQV-REQUIMTE, Departamento de Química, Universidade Nova de Lisboa, 2829-516 Monte de Caparica, Portugal; ○ orcid.org/0000-0003-0528-1967

Margarita Crespo - Departament de Química Inorgànica $i$ Orgànica, Secció de Qúmica Inorgànica, Universitat de Barcelona, E-08028 Barcelona, Spain; Institut de Biomedicina de la Universitat de Barcelona (IBUB), 08028 Barcelona,

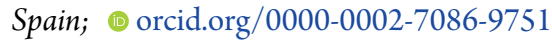

Complete contact information is available at: https://pubs.acs.org/10.1021/acs.inorgchem.0c00577

\section{Notes}

The authors declare no competing financial interest.

\section{ACKNOWLEDGMENTS}

The authors are grateful to the Spanish Ministerio de Ciencia, Innovación y Universidades (AEI/FEDER, UE Project CTQ2016-76120-P and CTQ2015-65040-P). FCT/MCTES is acknowledged for financial support through the Associate Laboratory for Green Chemistry, LAQV-REQUIMTE (UID/ QUI/50006/2013), the Coimbra Chemistry Centre (UID/ QUI/00313/2019), and through Project PTDC/QUI-QFI/ 
32007/2017 and Project "Hylight" (no. 031625) 02/SAICT/ 2017. We acknowledge funding by Fundo Europeu de Desenvolvimento Regional (FEDER) through Programa Operacional Factores de Competitividade (COMPETE) and project ROTEIRO/0152/2013. The research leading to these results received funding from Laserlab-Europe (grant agreement no. 284464, EC's Seventh Framework Programme).

\section{REFERENCES}

(1) Goswami, S.; Winkel, R. W.; Schanze, K. S. Photophysics and Nonlinear Absorption of Gold(I) and Platinum(II) Donor-Acceptor-Donor Chromophores. Inorg. Chem. 2015, 54 (20), 1000710014 .

(2) Jiang, X.; Zhu, N.; Zhao, D.; Ma, Y. New Cyclometalated Transition-Metal Based Photosensitizers for Singlet Oxygen Generation and Photodynamic Therapy. Sci. China: Chem. 2016, 59 (1), $40-52$.

(3) Rogers, J. E.; Slagle, J. E.; Krein, D. M.; Burke, A. R.; Hall, B. C.; Fratini, A.; McLean, D. G.; Fleitz, P. A.; Cooper, T. M.; Drobizhev, M.; et al. Platinum Acetylide Two-Photon Chromophores. Inorg. Chem. 2007, 46 (16), 6483-6494.

(4) Mei, J.; Ogawa, K.; Kim, Y.-G.; Heston, N. C.; Arenas, D. J.; Nasrollahi, Z.; McCarley, T. D.; Tanner, D. B.; Reynolds, J. R.; Schanze, K. S. Low-Band-Gap Platinum Acetylide Polymers as Active Materials for Organic Solar Cells. ACS Appl. Mater. Interfaces 2009, 1 (1), 150-161.

(5) Giménez, N.; Lalinde, E.; Lara, R.; Moreno, M. T. Design of Luminescent, Heteroleptic, Cyclometalated Pt II and Pt IV Complexes: Photophysics and Effects of the Cyclometalated Ligands. Chem. - Eur. J. 2019, 25 (21), 5514-5526.

(6) Millán, G.; Giménez, N.; Lara, R.; Berenguer, J. R.; Moreno, M. T.; Lalinde, E.; Alfaro-Arnedo, E.; López, I. P.; Pineiro-Hermida, S.; Pichel, J. G. Luminescent Cycloplatinated Complexes with Biologically Relevant Phosphine Ligands: Optical and Cytotoxic Properties. Inorg. Chem. 2019, 58 (2), 1657-1673.

(7) Herberger, J.; Winter, R. F. Platinum Emitters with Dye-Based r -Aryl Ligands. Coord. Chem. Rev. 2019, 400, 213048.

(8) Bandeira, S.; Gonzalez-Garcia, J.; Pensa, E.; Albrecht, T.; Vilar, R. A Redox-Activated G-Quadruplex DNA Binder Based on a Platinum(IV)-Salphen Complex. Angew. Chem., Int. Ed. 2018, 57 (1), 310-313.

(9) McKenzie, L. K.; Bryant, H. E.; Weinstein, J. A. Transition Metal Complexes as Photosensitisers in One- and Two-Photon Photodynamic Therapy. Coord. Chem. Rev. 2019, 379, 2-29.

(10) Geist, F.; Jackel, A.; Irmler, P.; Linseis, M.; Malzkuhn, S.; KussPetermann, M.; Wenger, O. S.; Winter, R. F. Directing Energy Transfer in Panchromatic Platinum Complexes for Dual Vis-Near-IR or Dual Visible Emission from $\sigma$-Bonded BODIPY Dyes. Inorg. Chem. 2017, 56 (2), 914-930.

(11) Gandioso, A.; Valle-Sistac, J.; Rodríguez, L.; Crespo, M.; FontBardía, M. Platinum(II) Compounds Containing Cyclometalated Tridentate Ligands: Synthesis, Luminescence Studies, and a Selective Fluoro for Methoxy Substitution. Organometallics 2014, 33 (2), 561570.

(12) Lázaro, A.; Serra, O.; Rodríguez, L.; Crespo, M.; Font-Bardia, M. Luminescence Studies of New $\left[\mathrm{C}, \mathrm{N}, \mathrm{N}^{\prime}\right]$ Cyclometallated Platinum(Ii) and Platinum(Iv) Compounds. New J. Chem. 2019, 43 (3), 1247-1256.

(13) Sierra, H.; Cordova, M.; Chen, C.-S. J.; Rajadhyaksha, M. Confocal Imaging-Guided Laser Ablation of Basal Cell Carcinomas: An Ex Vivo Study. J. Invest. Dermatol. 2015, 135 (2), 612-615.

(14) Shavaleev, N. M.; Adams, H.; Best, J.; Edge, R.; Navaratnam, S.; Weinstein, J. A. Deep-Red Luminescence and Efficient Singlet Oxygen Generation by Cyclometalated Platinum(II) Complexes with 8Hydroxyquinolines and Quinoline-8-Thiol. Inorg. Chem. 2006, 45 (23), 9410-9415.

(15) Haque, A.; Xu, L.; Al-Balushi, R. A.; Al-Suti, M. K.; Ilmi, R.; Guo, Z.; Khan, M. S.; Wong, W. Y.; Raithby, P. R. Cyclometallated
Tridentate Platinum(Ii) Arylacetylide Complexes: Old Wine in New Bottles. Chem. Soc. Rev. 2019, 48 (23), 5547-5563.

(16) Zhang, W.; Luo, Y.; Xu, Y.; Tian, L.; Li, M.; He, R.; Shen, W. The Electronic Structures and Photophysical Properties of Platinum Complexes with $\mathrm{C}^{\wedge} \mathrm{N}^{\wedge} \mathrm{N}$ Ligands: The Influence of the Carborane Substituent. Dalt. Trans. 2015, 44 (41), 18130-18137.

(17) Lu, W.; Mi, B.-X.; Chan, M. C. W.; Hui, Z.; Che, C.-M.; Zhu, N.; Lee, S.-T. Light-Emitting Tridentate Cyclometalated Platinum(II) Complexes Containing $\sigma$-Alkynyl Auxiliaries: Tuning of Photo- and Electrophosphorescence. J. Am. Chem. Soc. 2004, 126 (15), 49584971.

(18) Savel, P.; Latouche, C.; Roisnel, T.; Akdas-Kilig, H.; Boucekkine, A.; Fillaut, J.-L. Cyclometalated Platinum(Ii) with Ethynyl-Linked Azobenzene Ligands: An Original Switching Mode. Dalt. Trans. 2013, 42 (48), 16773-16783.

(19) Lanoë, P.-H.; Bozec, H. Le; Gareth Williams, J. A.; Fillaut, J.-L.; Guerchais, V. Cyclometallated Platinum(Ii) Complexes Containing Pyridyl-Acetylide Ligands: The Selective Influence of Lead Binding on Luminescence. Dalton Trans. 2010, 39 (3), 707-710.

(20) Sonogashira, K.; Fujikura, Y.; Yatake, T.; Toyoshima, N.; Takahashi, S.; Hagihara, N. Syntheses and Properties of Cis- and Trans-Dialkynyl Complexes of Platinum(II). J. Organomet. Chem. 1978, 145 (1), 101-108.

(21) Puttock, E. V.; Walden, M. T.; Williams, J. A. G. The Luminescence Properties of Multinuclear Platinum Complexes. Coord. Chem. Rev. 2018, 367, 127-162.

(22) Li, K.; Wan, Q.; Yang, C.; Chang, X. Y.; Low, K. H.; Che, C. M. Air-Stable Blue Phosphorescent Tetradentate Platinum(II) Complexes as Strong Photo-Reductant. Angew. Chem., Int. Ed. 2018, 57 (43), 14129-14133.

(23) Viola, E.; Donzello, M. P.; Ercolani, C.; Rizzoli, C.; Lever, A. B. P. Synthesis and Structure of Rare Zwitterionic Complexes Involving the Presence of $\mathrm{N}(\mathrm{Py}) \mathrm{MCl} 3-$ Moieties $(\mathrm{M}=\mathrm{Pt}(\mathrm{II}), \mathrm{Pd}(\mathrm{II}))$. Inorg. Chim. Acta 2018, 480, 101-107.

(24) Horng, M. L.; Gardecki, J. A.; Papazyan, A.; Maroncelli, M. Subpicosecond Measurements of Polar Solvation Dynamics: Coumarin 153 Revisited. J. Phys. Chem. 1995, 99 (48), 17311-17337.

(25) Toubia, I.; Nguyen, C.; Diring, S.; Ali, L. M. A.; Larue, L.; Aoun, R.; Frochot, C.; Gary-Bobo, M.; Kobeissi, M.; Odobel, F. Synthesis and Anticancer Activity of Gold Porphyrin Linked to Malonate Diamine Platinum Complexes. Inorg. Chem. 2019, 58 (18), 12395-12406.

(26) Yao, S.; Chen, L.; Jia, F.; Sun, X.; Su, H.; Liu, H.; Yang, L.; Wang, Z.; Wu, F.; Wang, K. Platinated Porphyrin Tailed with Folic Acid Conjugate for Cell-Targeted Photodynamic Activity. J. Lumin. 2019, 214 (June), 116552.

(27) Yang, M.; Deng, J.; Guo, D.; Zhang, J.; Yang, L.; Wu, F. A Folate-Conjugated Platinum Porphyrin Complex as a New CancerTargeting Photosensitizer for Photodynamic Therapy. Org. Biomol. Chem. 2019, 17 (21), 5367-5374.

(28) Shi, H.; Clarkson, G. J.; Sadler, P. J. Dual Action Photosensitive Platinum(II) Anticancer Prodrugs with Photoreleasable Azide Ligands. Inorg. Chim. Acta 2019, 489, 230-235.

(29) Xue, X.; Zhu, C.; Chen, H.; Bai, Y.; Shi, X.; Jiao, Y.; Chen, Z.; Miao, Y.; He, W.; Guo, Z. A New Approach to Sensitize Antitumor Monofunctional Platinum(II) Complexes via Short Time PhotoIrradiation. Inorg. Chem. 2017, 56 (7), 3754-3762.

(30) Kim, S.; Ohulchanskyy, T. Y.; Bharali, D.; Chen, Y.; Pandey, R. K.; Prasad, P. N. Organically Modified Silica Nanoparticles with Intraparticle Heavy-Atom Effect on the Encapsulated Photosensitizer for Enhanced Efficacy of Photodynamic Therapy. J. Phys. Chem. C 2009, 113 (29), 12641-12644.

(31) Lai, S. W.; Liu, Y.; Zhang, D.; Wang, B.; Lok, C. N.; Che, C. M.; Selke, M. Efficient Singlet Oxygen Generation by Luminescent 2(2'-Thienyl) Pyridyl Cyclometalated Platinum(II) Complexes and Their Calixarene Derivatives. Photochem. Photobiol. 2010, 86 (6), 1414-1420.

(32) Jana, A.; McKenzie, L.; Wragg, A. B.; Ishida, M.; Hill, J. P.; Weinstein, J. A.; Baggaley, E.; Ward, M. D. Porphyrin/Platinum(II) 
$\mathrm{C}^{\wedge} \mathrm{N}^{\wedge} \mathrm{N}$ Acetylide Complexes: Synthesis, Photophysical Properties, and Singlet Oxygen Generation. Chem. - Eur. J. 2016, 22 (12), 41644174.

(33) Pushpanandan, P.; Maurya, Y. K.; Omagari, T.; Hirosawa, R.; Ishida, M.; Mori, S.; Yasutake, Y.; Fukatsu, S.; Mack, J.; Nyokong, T.; et al. Singly and Doubly N-Confused Calix[4]Phyrin Organoplatinum(II) Complexes as Near-IR Triplet Sensitizers. Inorg. Chem. 2017, 56 (20), 12572-12580.

(34) Hu, X.; Ogawa, K.; Kiwada, T.; Odani, A. Water-Soluble Metalloporphyrinates with Excellent Photo-Induced Anticancer Activity Resulting from High Tumor Accumulation. J. Inorg. Biochem. 2017, 170, 1-7.

(35) Ware, W. R.; Cunningham, P. T. Fluorescence Lifetime and Fluorescence Enhancement of Perylene Vapor. J. Chem. Phys. 1966, 44 (11), 4364-4365.

(36) Seixas de Melo, J. S. The Influence of Oxygen on the Lifetime of Luminescent Probes. A Simple Device for Degassing Solutions for Fluorescence Measurements. Chem. Educ. 2005, 10 (05), 29-35.

(37) The analyses of fluorinated compounds present significant difficulty; see Fadeeva, V. P.; Tikhova, V. D.; Nikulicheva, O. N. J. Anal. Chem. 2008, 63, 1094-1106. The analysis obtained for 2a-c are the best data obtained and have been included in the text. NMR and excitation spectra can support the purity of all compounds.

(38) Kristiansen, M.; Scurlock, R. D.; Iu, K. K.; Ogilby, P. R. ChargeTransfer State and Singlet Oxygen (1.DELTA.g O2) Production in Photoexcited Organic Molecule-Molecular Oxygen Complexes. J. Phys. Chem. 1991, 95 (13), 5190-5197.

(39) Seixas de Melo, J.; Fernandes, P. Spectroscopy and Photophysics of 4- and 7-Hydroxycoumarins and Their Thione Analogs. J. Mol. Struct. 2001, 565-566, 69-78.

(40) Striker, G.; Subramaniam, V.; Seidel, C. A. M.; Volkmer, A. Photochromicity and Fluorescence Lifetimes of Green Fluorescent Protein. J. Phys. Chem. B 1999, 103 (40), 8612-8617.

(41) Pina, J.; Seixas de Melo, J. S.; Eckert, A.; Scherf, U. Unusual Photophysical Properties of Conjugated, Alternating Indigo-Fluorene Copolymers. J. Mater. Chem. A 2015, 3 (12), 6373-6382.

(42) Snellenburg, J. J.; Laptenok, S. P.; Seger, R.; Mullen, K. M.; van Stokkum, I. H. M. Glotaran: A Java -Based Graphical User Interface for the R Package TIMP. J. Stat. Softw. 2012, 49 (3), 1-22.

(43) Hooft, R. W. W. COLLECT; Nonius BV: Delft, The Netherlands, 1998.

(44) Otwinowski, Z.; Minor, W. Methods in Enzymology. Methods Enzymol. 1997, 276, 307-326.

(45) Sheldrick, G. M. SADABS, version 2008/2; University of Göttingen: Germany, 1996.

(46) Sheldrick, G. M. SHELXT - Integrated space-group and crystalstructure determination. Acta Crystallogr., Sect. A: Found. Adv. 2015, A71, 3-8.

(47) Sheldrick, G. M. Crystal structure refinement with SHELXL. Acta Crystallogr., Sect. C: Struct. Chem. 2015, C71, 3-8.

(48) Dolomanov, O. V.; Bourhis, L. J.; Gildea, R. J.; Howard, J. A. K.; Puschmann, H. OLEX2: a complete structure solution, refinement and analysis program. J. Appl. Crystallogr. 2009, 42, 339-341.

(49) Shao, Y.; Gan, Z.; Epifanovsky, E.; Gilbert, A. T. B.; Wormit, M.; Kussmann, J.; Lange, A. W.; Behn, A.; Deng, J.; Feng, X.; et al. Advances in Molecular Quantum Chemistry Contained in the QChem 4 Program Package. Mol. Phys. 2015, 113 (2), 184-215.

(50) Spartan'18 v. 1.4.0.; Wavefunction, Inc.: Irvine, CA, 2019.

(51) Becke, A. D. Density-Functional Thermochemistry. III. The Role of Exact Exchange. J. Chem. Phys. 1993, 98 (7), 5648-5652.

(52) Lee, C.; Yang, W.; Parr, R. G. Development of the ColleSalvetti Correlation-Energy Formula into a Functional of the Electron Density. Phys. Rev. B: Condens. Matter Mater. Phys. 1988, 37 (2), 785-789.

(53) Hariharan, P. C.; Pople, J. A. The Influence of Polarization Functions on Molecular Orbital Hydrogenation Energies. Theor. Chim. Acta 1973, 28 (3), 213-222.

(54) Francl, M. M.; Pietro, W. J.; Hehre, W. J.; Binkley, J. S.; Gordon, M. S.; DeFrees, D. J.; Pople, J. A. Self-consistent Molecular
Orbital Methods. XXIII. A Polarization-type Basis Set for Second-row Elements. J. Chem. Phys. 1982, 77 (7), 3654-3665.

(55) Hay, P. J.; Wadt, W. R. Ab Initio Effective Core Potentials for Molecular Calculations. Potentials for $\mathrm{K}$ to $\mathrm{Au}$ Including the Outermost Core Orbitals. J. Chem. Phys. 1985, 82 (1), 299-310.

(56) Cossi, M.; Rega, N.; Scalmani, G.; Barone, V. Energies, Structures, and Electronic Properties of Molecules in Solution with the C-PCM Solvation Model. J. Comput. Chem. 2003, 24 (6), 669681.

(57) Bartocci, S.; Sabaté, F.; Bosque, R.; Keymeulen, F.; Bartik, K.; Rodríguez, L.; Dalla Cort, A. Colorimetric and Fluorescence "Turnon" Recognition of Fluoride by a Maleonitrile-Based Uranyl SalenComplex. Dyes Pigm. 2016, 135, 94-101. 